\title{
THE OTHER SIDE OF THE COIN: FUNCTIONAL AND STRUCTURAL VERSATILITY
} OF ADF/COFILINS

\author{
Gábor Hild $^{\text {a, b }}$, Lajos Kalmár ${ }^{\text {d }}$, Roland Kardos ${ }^{\text {a, b }}$, Miklós Nyitrai ${ }^{\text {a, b, c }}$, Beáta Bugyi a, b \\ ${ }^{a}$ University of Pécs, Medical School, Department of Biophysics, Szigeti str. 12, H-7624 Pécs, \\ Hungary \\ ${ }^{\mathrm{b}}$ Szentágothai Research Center, Ifjúság str. 34, H-7624 Pécs, Hungary \\ c 'MTA-PTE Nuclear and Mitochondrial Interactions Research Group' Hungarian Academy of \\ Sciences, Office for Subsidized Research Units, Nádor str. 7, H-1051 Budapest, Hungary \\ ${ }^{\mathrm{d}}$ Institute of Enzymology, Hungarian Academy of Sciences, Research Centre for Natural \\ Sciences, PO Box 7, H-1518 Budapest, Hungary \\ Corresponding author: Beáta Bugyi \\ Postal address: University of Pécs, Medical School, Department of Biophysics, Szigeti str. 12, \\ H-7624 Pécs, Hungary \\ Tel.: +36-72-536 265; Fax: +36-72-536 261 \\ E-mail: beata.bugyi@aok.pte.hu
}




\begin{abstract}
Several cellular processes rely on the fine tuning of actin cytoskeleton. A central component in the regulation of this cellular machinery is the ADF-H domain proteins. Despite sharing the same domain, ADF-H domain proteins produce a diverse functional landscape in the regulation of the actin cytoskeleton. Recent findings emphasize that the functional and structural features of these proteins can differ not only between ADF-H families but even within the same family. The structural and evolutional background of this functional diversity is poorly understood. This review focuses on the specific functional characteristics of ADF-H domain proteins and how these features can be linked to structural differences in the ADF-H domain and also to different conformational transitions in actin. In the light of recent discoveries we pay special attention to the $\mathrm{ADF} /$ cofilin proteins to find tendencies along which the functional and structural diversification is governed through the evolution.
\end{abstract}

Keywords: actin, cytoskeleton, ADF-H domain, ADF/cofilin, nucleotide, conformational dynamics 


\section{INTRODUCTION}

The actin cytoskeleton is a dynamic assembly of structurally and functionally diverse actin-based protein networks. The basic elements of the actin cytoskeleton are the globular actin monomers (G-actin). The structure of the G-actin is composed of two main domains, which are further divided into four subdomains (SD1-4) (Figure 1A). To form cellular actin structures actin monomers can assemble into fiber-like polymers called actin filaments (Factin). Structurally F-actin is built from two helices, a double-stranded, right-handed helix and a single-stranded left-handed helix (Figure 2A). The structural integrity of the filament is established by both inter- and intrastrand contacts, which are formed within the single- and double-stranded helix, respectively. Actin has a high-affinity adenosine-nucleotide and divalent cation binding site enclosed by SD2 and SD4 (Figure 1A). The bound nucleotide (ATP, ADP-Pi, or ADP) in complex with a divalent cation (physiologically it is thought to be $\mathrm{Mg}^{2+}$ ) is buried in the structure of actin. The actin monomer has a very low ATPase activity ( $\mathrm{k}_{\text {hydrolysis }}=0.6 \mathrm{~h}^{-1}$, for bovine thymus $\mathrm{Mg}^{2+}-\beta / \gamma$ actin isoforms) (Schüler et al., 2006; Schüler et al., 2000). However, this activity is highly enhanced when actin monomers assemble into actin filaments (Carlier et al., 1984; Pantaloni et al., 1985; Pollard and Weeds, 1984). The ATPase activity of actin is strongly coupled to the dynamics of the actin cytoskeleton. The inherent nucleotide-dependent dynamics of actin can be influenced by different actin-binding proteins (ABPs), which can tune the nucleotide-dependent remodeling of the actin cytoskeleton with high specificity by effectively distinguishing between the different nucleotide states of actin (ATP, ADP-Pi, or ADP-bound actin monomers and subunits). While several details have become clear, the structural bases for the nucleotide-dependent functions of the ABPs are still not completely understood. Systematic analysis and understanding of the information is difficult due to the complexity of the corresponding conformational transitions and the related functions. Deciphering the conformational changes in actin induced by its binding partners led to extensive investigations in various fields of biology. Another important aspect of the nucleotide-dependent regulation of the actin cytoskeleton is the way as certain ABPs adapted through evolution to targeting the different nucleotide states of monomeric and/or filamentous actin specifically. We attempt here to summarize our current knowledge about the nucleotide-dependent regulation of the actin cytoskeleton by ABPs. In the light of recent discoveries we pay special attention to the functional specifications of the actin-depolymerizing factor homology (ADF-H) domain proteins, including the ADF/cofilin family, and also try to find tendencies along which the structural changes can be linked to their specific biochemical functions. For details of the cell-biological aspects, the interactions with other proteins and the regulation of the ADF-H domain proteins see excellent reviews (Bernstein and Bamburg, 2010; Poukkula et al., 2011; Van Troys et al., 2008).

\section{THE NUCLEOTIDE-DEPENDENT REGULATION OF THE ACTIN CYTOSKELETON}

According to the basic concept of treadmilling (Figure 3, gray box) (Pantaloni et al., 2001; Wegner, 1976) ATP-bound actin monomers are thought to be the polymerization competent form of actin in cells. They are far more likely to incorporate at the barbed end of 
the filaments with higher probability than ADP-G-actin is. After the integration of ATPbound actin into the filament the terminal phosphoanhydride bond of the nucleotide is hydrolyzed and the inorganic $\gamma$-phosphate (Pi) is released, resulting in ADP-Pi and ADP-actin subunits, respectively. The ADP-bound actin subunits dissociate predominantly from the pointed end of the filaments (Carlier et al., 1988; Carlier et al., 1987; Korn et al., 1987; Pollard, 1986, 2007; Yao et al., 1999; Yao and Rubenstein, 2001). This process forms the basis of the nucleotide-driven directed assembly and disassembly of actin filaments.

In cells actin treadmilling is enhanced by the combined nucleotide-dependent activities of ABPs (Didry et al., 1998; Renault et al., 2008). The formin family of proteins and the actin-related protein (Arp)2/3 complex machinery can catalyze the de novo assembly of actin filaments preferentially by binding to the ATP-bound actin units (Chereau et al., 2005; Ichetovkin et al., 2002; Romero et al., 2007). The disassembly of actin filaments can be enhanced by members of the ADF-H domain-containing ADF/cofilin proteins, which preferentially bind to the ADP-loaded regions of the filaments and accelerate the dissociation of actin subunits (Blanchoin and Pollard, 1999; Carlier et al., 1997; Suarez et al., 2011). The recycling of the released ADP-bound actin monomers into a polymerization competent ATPbound form is proposed to be driven by profilin that enhances the exchange of the bound nucleotide on free G-actin. Profilin also directs actin assembly since the profilin-bound ATPG-actin can exclusively associate to the barbed not to the pointed end of the filaments (Selden et al., 1999; Wen et al., 2008; Wolven et al., 2000). Besides profilin, the cyclase-associated proteins (CAPs) can also catalyze the nucleotide exchange on ADF/cofilin-bound ADP-actin monomers and convert them into polymerization competent ATP-G-actin in vitro (Chaudhry et al., 2013; Chaudhry et al., 2007; Nomura and Ono, 2013). The effect on the nucleotideexchange rate is the most highly conserved activity of CAPs present in apicomplexans as well as in mammals (Makkonen et al., 2013). The mutations that abolish this activity in vitro impair the in vivo activities of CAPs suggesting the biological relevance of this function (Chaudhry et al., 2010).

\section{ACTIN-DEPOLYMERIZING FACTOR HOMOLOGY DOMAIN PROTEIN FAMILIES}

Amongst the ABPs, the ADF-H domain proteins are one notable example how to adapt in a remarkable way to provide versatile regulation of actin remodeling using the same domain fold. Recent findings indicate that despite sharing the same domain, the activities of ADF-H domain proteins can vary, differ and can even be opposing between and within different ADF-H domain protein families, depending on the number and specific features of the ADF-H domains and also on other domains and interacting partners of the given protein. Despite the similar architecture, differences in the conserved protein fold seem to tailor ADF$\mathrm{H}$ domain proteins to outline a diverse functional landscape in the regulation of actin-based processes. The detailed picture of the structural and evolutional origin of this diversity has not been established yet.

The ADF-H domain is a small globular domain that can be found in different families of proteins including ADF/cofilin, twinfilin, actin-binding protein 1 (Abp1), developmentally regulated brain protein (drebrin), coactosin and glia maturation factor (GMF) (Table 1.). High 
resolution 3D crystal and NMR solution structures of ADF-H domains from different proteins show that the basic ADF-H fold is composed of four alpha helices ( $\alpha 1-4)$ surrounded by six beta strands ( $\beta 1-6)$ (Fedorov et al., 1997; Goroncy et al., 2009; Hellman et al., 2004; Leonard et al., 1997; Paavilainen et al., 2008; Singh et al., 2011; Strokopytov et al., 2005). The binding partners of the ADF-H domain proteins can be actin monomers, filaments and the Arp $2 / 3$ complex. The interactions are mediated by two separate binding regions of the ADF-H domain, called the G-site and the F-site (Figure $1 B$ and $2 B$ ). The G-site is sufficient to interact with actin monomers or the Arp $2 / 3$ complex, while both the G- and the F-sites are required for actin filament binding. The atomic structure of the $\mathrm{C}$ terminal ADF-H domain of mouse twinfilin-1 in complex with rabbit $\alpha$-skeletal G-actin revealed that the G-site is composed of the N-terminal residues (Q176-I181), the $\alpha 4$ helix (I266-S274) and an extra loop (K294-E302) of the ADF-H domain. This site is incorporated between SD1 and SD3 at the barbed face of the actin monomer and forms a contact with the hydrophobic groove and the C-terminus (Figure 1B) (Paavilainen et al., 2008). Based on the 3D reconstruction of rabbit $\alpha$ skeletal F-actin decorated with human cofilin-2, the interaction of ADF-H domains with actin filaments is mediated by two distinct regions, which bind to two adjacent actin subunits within the single-stranded helix of the actin filament (Galkin et al., 2011). One of these resembles the G-site found in the twinfilin-G-actin complex. This region of human cofilin-2 forms a contact with the barbed face of the upper actin subunit (Figure 2B). The other region is composed of two distinct surface loops, loop S94-D98 and loop G154-V158, which bind to the SD4 and SD1 region of the lower actin subunit, respectively. These contact surfaces, which are crucial for F-actin binding but not for the interaction with G-actin form the F-site (Lappalainen et al., 1997).

Conventionally, each ADF-H domain family can be associated with canonical activities in the regulation of actin dynamics (Figure 3, Table 1.). Recent findings emphasize that the individual members of each ADF-H domain family should not be stereotypically associated with common functional features and on the basis of the protein nomenclature function assignment can be misleading.

Twinfilins are composed of two ADF-H domains (the N-terminal and C-terminal Twf$\mathrm{N}$ and Twf-C, respectively) separated by a linker. Despite the two ADF-H domains, only Twf$\mathrm{C}$ interacts with actin monomers forming a $1: 1$ complex. Twinfilins preferentially bind to the ADP form of G-actin (Goode et al., 1998; Ojala et al., 2002). Upon monomer binding twinfilins affect the nucleotide exchange rate of the actin monomers. All twinfilins studied so far slow down the exchange of the actin-bound nucleotide (Goode et al., 1998). G-actin is sequestered in its complex with twinfilins, so actin monomers are removed from the main stream of actin dynamics by twinfilin. As exceptions, some twinfilins can interact with the actin filaments, as well. Mouse twinfilin-1, besides sequestration, caps the barbed end of actin filaments, which requires both of its ADF-H domains (Helfer et al., 2006). The fact that $D$. melanogaster and S. cerevisiae twinfilins do not have capping activity (Helfer et al., 2006) suggests that this function appeared at a later stage of evolution. Also, S. cerevisiae twinfilin1 was shown to bind actin filaments and exhibit $\mathrm{pH}$-dependent severing activity $(\mathrm{pH}<6)$ in vitro for both $S$. cerevisiae and rabbit $\alpha$-skeletal actin filaments (Moseley et al., 2006). The severing activity is consistent with the decreased turnover of cortical actin patches in twinfilin mutant yeast cells observed in vivo (Moseley et al., 2006). Therefore, S. cerevisiae twinfilin 
by enhancing actin filament disassembly resembles the canonical activities of the ADF/cofilin family. It is not known whether the disassembly-promoting activity of twinfilin is conserved in higher eukaryotes.

Coactosin, drebrin and Abpl contain one ADF-H domain. These members of the ADF-H domain family were shown to bind exclusively filamentous and not monomeric actin.

Coactosin is composed of a single ADF-H domain. Actin filament binding of coactosin was shown to interfere with the filament capping activity of capping protein in vitro (de Hostos et al., 1993; Provost et al., 2001; Rohrig et al., 1995). This may be of biological importance, since a recent study showed that in neural crest and N1E-115 neuroblastoma cells coactosin co-localizes with capping protein and mediates neurite extension and cell migration by actively promoting actin assembly (Hou et al., 2013). It is not known whether coactosin can antagonize the activity of capping protein through the alteration of actin filament structure, which would be incompatible with capping protein binding, or through a direct interaction with capping protein. For twinfilins from $S$. cerevisiae and $S$. pombe direct interaction with capping protein was shown to be required for their proper localization but this interaction did not interfere with capping protein function (Falck et al., 2004; Palmgren et al., 2001; Vartiainen et al., 2003).

Drebrin is a multidomain protein. Besides its N-terminal ADF-H domain it also contains an upstream central helical charged motif containing a special sequence that is proposed to be the actin-binding domain of the protein since it affects the actin remodeling in the same way as the full length protein (Grintsevich et al., 2010). Interestingly, the isolated ADF-H domain of drebrin does not seem to bind actin filaments in vitro (Ishikawa et al., 1994). Drebrin from M. musculus stabilizes actin filaments upon binding and inhibits their depolymerization (Ishikawa et al., 1994; Mikati et al., 2013). The binding of drebrin to F-actin induces conformational changes in the filament structure. These structural alterations result in the stabilization of both the inter- and intrastrand contacts and the increase in the mechanical stability of the filament $(\sim 50 \%$ increase in both the persistence length and the elastic modulus) (Mikati et al., 2013; Sharma et al., 2011).

Abp1 is also a modular protein, which possesses an N-terminal ADF-H domain, a central acidic motif, a proline-rich region and a C-terminal Src homology 3 (SH3) domain. Besides actin filament binding $S$. cerevisiae Abp1 was shown to stimulate the nucleationpromoting activity of the Arp2/3 complex machinery, which requires two acidic regions in its central acidic motifs (Goode et al., 2001; Quintero-Monzon et al., 2005). Mutagenesis studies revealed that actin filament binding of Abp1 is required for the activation of the Arp2/3 complex, as well (Quintero-Monzon et al., 2005). These observations suggest that Abp1 may enhance the activity of the Arp2/3 complex by promoting its interaction with the actin filament. On the other hand, the activity of the Arp2/3 complex is sensitive to the conformation of the actin filaments (Risca et al., 2012) and ADF-H domain proteins can affect the structure of the filament. Based on these connections, it is hypothesized that, besides the direct interaction with the Arp2/3 complex, Abp1 can also alter the conformation of actin filament structure that would favor the nucleation by the Arp2/3 complex machinery.

$G M F$ with one ADF-H domain does not bind either forms of actin but it directly interacts with the Arp2/3 complex. In contrast to Abp1, GMF interferes with the activity of the Arp2/3 complex (Boczkowska et al., 2013; Luan and Nolen, 2013; Ydenberg et al., 2013). 
This property of GMF is conserved between yeast and mouse (Chaudhry et al., 2007; Gandhi et al., 2010; Nakano et al., 2010). The very recent crystal structure of the complex of $M$. musculus GMFy and B. taurus Arp2/3 complex revealed that GMF interacts with the actinrelated Arp2 subunit of the Arp2/3 complex. The binding mode is similar to the interaction of twinfilins or ADF/cofilins with G-actin. The G-site of GMF incorporates into the barbed face of the Arp2 subunit between SD1 and SD3 (Luan and Nolen, 2013). Another similar feature of the binding is that GMF prefers the ADP-state of the Arp2 subunit (Boczkowska et al., 2013). Fitting the GMF-Arp2/3 complex structure into the model of the branch junction constructed from electron tomography (Rouiller et al., 2008) shows that besides interaction with the Arp2 subunit GMF using an interface similar to the F-site of ADF/cofilins can also interact with the SD2 and SD1 region of the adjacent actin subunit in the Arp2/3 complex generated daughter filament (Luan and Nolen, 2013). The structural data is consistent with recent findings that the activity of GMF requires both the G- and the F-sites and that GMF promotes the dissociation of Arp2/3 complex generated branches using a cofilin-like severing mechanism (Ydenberg et al., 2013). Moreover, the model revealed that the movement of GMF at the branch junction towards the first actin subunit of the daughter filament results in a steric clash, which could destabilize the Arp2-actin contacts or could interfere with the association of G-actin to the branch junction (Luan and Nolen, 2013). Importantly, the analysis of the crystal structure suggests that the exclusive interaction of GMF with the Arp2 subunit of the complex and not with the Arp3 subunit or G-actin is established by specific structural elements of both GMF and the Arp2 (Luan and Nolen, 2013). First, extensions in SD3 and at the C-terminus of Arp3, which are not present in the Arp2 subunit or G-actin result in steric clashes that are not compatible with GMF binding. The specificity of GMF to Arp2 over G-actin is established by amino acid substitutions in the $\beta 5-\alpha 4$ loop and the Nterminus of $\alpha 3$ in GMF compared to the G-site of Twf-C, as well as in the Arp2 subunit compared to G-actin. These amino acid differences provide the basis for specific polar contact pairs, which are formed exclusively between GMF and Arp2 or Twf-C and G-actin.

\section{ADF/COFILINS}

The founding and the most intensively studied members of the ADF-H domain protein family so far are the $A D F /$ cofilins, which were identified in blood plasma and chicken brain on the basis of their activity to enhance actin filament disassembly (Bamburg et al., 1980; Harris et al., 1980). ADF/cofilins are built from a single ADF-H domain and can interact with filamentous and monomeric actin, as well. The main isoforms of the ADF/cofilin family are cofilin-1 (non-muscle isoform), cofilin-2 (muscle specific isoform) and ADF (or destrin, mainly found in non-muscle cells) (Bernstein and Bamburg, 2010). One of the main functions of ADF/cofilins is to regulate actin dynamics (Figure 3). The modes of action of ADF/cofilins highly depend on the concentration of the ADF/cofilins. When ADF/cofilins are present in low concentrations they prefer to sever the actin filaments and promote the depolymerization of the pointed end of the filament. While at high concentrations they can increase the polymerization by nucleating new actin filaments (Andrianantoandro and Pollard, 2006). $\mathrm{ADF} /$ cofilins can keep the actin filaments in a very dynamic state by inducing a steady regime in the filament length fluctuation (Roland et al., 2008). The ADF/cofilins can bind actin 
monomers as well (Paavilainen et al., 2004). During complex formation with G-actin $\mathrm{ADF} /$ cofilin can shift the nucleotide binding cleft of actin into a "closed" conformation (Kardos et al., 2009), a change that can probably be responsible for the decreased nucleotide exchange on monomeric actin in the presence of ADF/cofilin (Nishida, 1985; Paavilainen et al., 2008). Although the ADF-H domain proteins are mainly localized in the cytosol, some of them can be found in the nucleus of the cells, as well (Castano et al., 2010; Chhabra and dos Remedios, 2005). ADF/cofilins within the nucleus of the cells are associated to rod-like actin filament structures under stress conditions (Ono et al., 1996; Pendleton et al., 2003) and in complex with monomeric actin, as well (Chhabra and dos Remedios, 2005). The cofilin main function is thought to be helping the translocation of actin into the nucleus (Chhabra and dos Remedios, 2005; Pendleton et al., 2003). The ADF-H domain proteins (e.g. cofilin, twinfilin) can also be very active around the cellular protrusions (lamellipodia, invadopodia) in collaboration with some other type of actin binding proteins as well (e.g. Arp2/3, cortactin) (Oser and Condeelis, 2009; van Rheenen et al., 2009; Vartiainen et al., 2003).

\section{THE INTERACTION OF ADF/COFILINS WITH ACTIN FILAMENTS}

\section{PREFERENTIAL BINDING TO ADP-F-ACTIN}

A canonical feature of the $\mathrm{ADF} /$ cofilin-actin filament interaction is that $\mathrm{ADF} / \mathrm{cofilins}$ preferentially associate to the ADP-bound actin subunits over ATP-bound subunits (Blanchoin and Pollard, 1999; Suarez et al., 2011). The nucleotide-dependent binding of $\mathrm{ADF} /$ cofilins to F-actin presumably originates from the structural differences between ATP, ADP-Pi and ADP containing segments of the filament. Single particle analysis on electron micrographs reconstructing different segments of the actin filament revealed that the contact between SD1 and SD2 of two adjacent subunits within the single-stranded helix of the filament depends on the nucleotide state of actin. In ATP-loaded (at the barbed end) and ADP-Pi-loaded (in the middle of the filament) subunits the contacts are stronger, while this contact does not exist in the ADP-loaded segments (at the pointed end) (Galkin et al., 2003). It was demonstrated by chemical crosslinking of SD1 and SD2 of two adjacent actin subunits that the strength of the contact between SD1 and SD2 influences the occupancy of actin filaments by $\mathrm{ADF} / \mathrm{cofilin}$. Based on these findings, it was proposed that conditions that weaken the interaction between SD1 and SD2 promote the binding of ADF/cofilin to actin, while conditions that strengthen this connection attenuate the ADF/cofilin-F-actin interaction (Galkin et al., 2003). In accord with this, ATP hydrolysis and Pi release upon actin assembly weakens the interaction between SD1 and SD2 (Belmont et al., 1999; Sablin et al., 2002) suggesting that the affinity of ADF/cofilins to F-actin gradually increases from the ATP- to the ADP-containing segments.

Although the preferential binding of ADF/cofilins to ADP-F-actin is a common feature of the ADF/cofilin family members, some ADF/cofilin isoforms can interact with ATP or ADP-Pi containing actin filaments, as well. A. thaliana ADF and A. castellani actophorin can bind weakly to F-actin in the presence of BeFx that mimics the ADP-Pi state of the filament (Blanchoin and Pollard, 1999; Carlier et al., 1997). Xenopus ADF/cofilin can interact with AMP-PNP (non-hydrolysable ATP analogue) actin filaments that mimics the ATP state 
of F-actin (Rosenblatt et al., 1997). Yeast cofilin associates to ADP-Pi actin filaments in the same extent as to ADP-F-actin but with slower kinetics (Chan et al., 2009; Gandhi et al., 2009; Muhlrad et al., 2006). Interestingly, S. cerevisiae cofilin and A. castellanii actophorin was shown to actively influence the chemical state of F-actin by allosterically catalyzing the Pi release rate from actin subunits (Blanchoin and Pollard, 1999; Suarez et al., 2011).

\section{STABILIZATION OR DISASSEMBLY OF F-ACTIN}

Canonically the functional outcome of the ADF/cofilin-F-actin interaction depends on the stoichiometry and the $\mathrm{pH}$ (Table 1.). At sub-stoichiometric ADF/cofilin : actin ratio the binding results in the weakening of the mechanical properties of actin filaments (decreased persistence length, increased bending and torsional flexibility (McCullough et al., 2008; Prochniewicz et al., 2005)) that leads to the destabilization and the enhancement of filament disassembly. F-actin destabilization occurs preferentially at the ADF/cofilin-free segments of the filaments. In contrast, saturating amount of $\mathrm{ADF} /$ cofilin does not result in filament disassembly (Andrianantoandro and Pollard, 2006; Elam et al., 2013; Pavlov et al., 2007; Suarez et al., 2011). This dual effect of ADF/cofilins on actin filament dynamics was proposed to result from unique and combined conformational rearrangements in the $\mathrm{ADF} /$ cofilin-bound filament. 3D reconstruction of rabbit $\alpha$-skeletal actin filaments decorated with plant ADF or human cofilin-2 revealed that upon binding ADF/cofilin disrupts the connection between SD1 and SD2 of adjacent subunits in the single-stranded helix of F-actin and forms a direct contact with them (Figure 2B) (Galkin et al., 2011; Galkin et al., 2001; Galkin et al., 2003). This direct contact as a bridge, results in net stabilization of subunitsubunit contacts by short-range steric effects. In contrast, the propagation of the local weakening of the F-actin structure, as long-range allosteric effects, results in the destabilization of both the inter- and the intrastrand filament contacts in the ADF/cofilin free segments of the actin filament, and consequently enhanced filaments disassembly (Aihara and Oda, 2013; Bobkov et al., 2006).

Increasing the $\mathrm{pH}$ from 6 to 8 gradually shifts the F-actin binding activity to F-actin depolymerizing activity, an opposite tendency that was observed for $S$. cerevisiae twinfilin-1 (Moseley et al., 2006). However, this is not a common feature of all ADF/cofilins (Table 2A). The $\mathrm{pH}$ sensitivity is more pronounced for the ADF proteins and in higher vertebrates. The $\mathrm{ADF} /$ cofilin-F-actin interaction is generally thought to show positive cooperativity. However, the nature of the binding of $\mathrm{ADF} /$ cofilins to actin, i.e. positively cooperative versus noncooperative, seems to depend on the isoforms of both proteins (Table 2A). The binding of yeast cofilin to both yeast and rabbit $\alpha$-skeletal actin is non-cooperative (Bobkov et al., 2002). Similarly, A. castellanii actophorin (ADF) binds non-cooperatively to A. castellanii F-actin, however, actophorin exhibits cooperative binding to rabbit $\alpha$-skeletal F-actin. The binding of human non-muscle cofilin-1 to non-muscle $\beta$ and $\gamma$ actin isoforms is more cooperative than to rabbit $\alpha$-skeletal actin filaments (De La Cruz, 2005). Consequently, the cooperative versus non-cooperative binding seems to be a specific feature of a given ADF/cofilin and actin pair.

\section{TO BIND OR NOT TO BIND}


Notably, while actin monomer binding is characteristic for all ADF/cofilins (see below) filament binding is not conserved through the evolution (Table 2A). Interestingly, some Apicomplexan ADF/cofilins from lower eukaryotes do not bind filamentous actin under in vitro conditions (Table 2A) (Mehta and Sibley, 2010; Schüler et al., 2005a, b; Singh et al., 2011). The lack of the interaction with actin filaments for the $T$. gondii ADF was also detected in homologous system using $T$. gondii actin. L. donovani cofilin increases the amount of unassembled actin in the case of L. donovani actin but not in the case of rabbit $\alpha$ skeletal actin, again highlighting the importance of homologous systems (Kumar et al., 2012). The 3D crystal structure of $P$. falciparum ADF1 and the homology model of $T$. gondii ADF structure revealed that while these ADF/cofilins conserved the monomer binding sites, the key actin filament binding motifs (such as the F-loop, $\beta 6$ strand and the C-terminal $\alpha 4$ helix) are shorter or completely missing. These differences in the F-site are proposed to form the structural basis for the missing interactions with filamentous actin (Mehta and Sibley, 2010; Singh et al., 2011). This special feature of these Apicomplexan ADFs suggests that they adapted for different functions in the remodeling of the actin cytoskeleton as compared to the ADFs from higher vertebrates.

\section{THE INTERACTION OF ADF/COFILINS WITH ACTIN MONOMERS}

\section{PREFERENTIAL BINDING TO ADP-G-ACTIN}

ADF/cofilins, similarly to twinfilins, bind monomeric actin. Only these two members of the ADF-H domain protein family can bind to G-actin. Despite the fact that ADF/cofilins and twinfilins are composed of one and two ADF-H domains, respectively, both proteins form a $1: 1$ complex with actin monomers. A conserved general feature of the monomer-binding of ADF-H domains is that both ADF/cofilins and twinfilins bind to G-actin in a nucleotidedependent manner, having higher affinity to ADP-G-actin than to ATP-G-actin (Table 1.). Based on different methods (molecular dynamics simulations, chemical crosslinking, mutagenesis, synchrotron protein footprinting), it was shown that the ADF-H domains of ADF/cofilins bind monomeric actin in a similar fashion to Twf-C (Paavilainen et al., 2008; Grintsevich et al., 2008; Lappalainen et al., 1997; Makkonen et al., 2013; Wriggers et al., 1998) (Figure 1B). In contrast, a 3D structural model of yeast cofilin with rabbit $\alpha$-skeletal actin constructed from radiolytic oxidative protein footprinting combined with mass spectrometry results suggested that the ADF-H domain of yeast cofilin can bind to the cleft between SD1 and SD2 of an actin monomer (Kamal et al., 2007). This binding mode of $\mathrm{ADF} /$ cofilin was further proposed on the basis of analytical ultracentrifugation, as in the presence of excess cofilin a $2: 1$ cofilin : actin complex was detected. Also, chemical crosslinking combined with MALDI MS/MS revealed that regions around SD2 of actin are involved in the interaction with ADF/cofilin (Benchaar et al., 2007). The functional significance of this second binding mode of ADF/cofilins is not known. The lower affinity binding site that can be occupied only when excess $\mathrm{ADF} /$ cofilin is present might be important in the actin assembly and nucleation promoting activity of human and $S$. pombe ADF/cofilins, which was detected in vitro at high cofilin : actin ratio (Andrianantoandro and Pollard, 2006; Ghosh et al., 2004). 
The monomer binding ability of ADF/cofilins is evolutionarily conserved, in contrast to the lack of filament binding of some $\mathrm{ADF} /$ cofilins (such as $T$. gondii $\mathrm{ADF}$ and $P$. falciparum ADF1) (Table 2B). It should be noted that the lack of filament binding does not necessarily reflect the same functioning on actin monomers. T. gondii ADF even without Factin binding enhances the disassembly of $T$. gondii actin filaments and also inhibits their assembly, suggesting that it could function as a monomer sequestering protein, similarly to twinfilins (Mehta and Sibley, 2010). In contrast, P. falciparum ADF1 does not affect the assembly of $P$. falciparum actin (Schüler et al., 2005a), which is inconsistent with the sequestering activity. Interestingly, $P$. falciparum ADF1 can enhance actin filament disassembly despite having a very weak ability to bind actin filaments (Wong et al., 2011).

\section{INHIBITION OR STIMULATION OF THE NUCLEOTIDE EXCHANGE RATE OF G-ACTIN}

Like twinfilins, ADF/cofilins affect the nucleotide exchange rate of the actin monomers upon binding. Many ADF/cofilins slow down the nucleotide exchange rate on monomeric actin similarly to twinfilins (Table $2 B$ ). However, comparative functional analysis revealed that this is not an inherent conserved feature of ADF/cofilins (Table 2B). Interestingly, recent findings demonstrate that most of the $\mathrm{ADF} /$ cofilins belonging to the phyla Euglenozoa, Ciliophora and Apicomplexa stimulate nucleotide exchange on rabbit $\alpha$ skeletal actin and also in homologous systems, such as $P$. falciparum ADFs on $P$. falciparum actin and T. gondii ADF on $T$. gondii actin, indicating that this feature is a biologically relevant function of these ADFs (Kumar et al., 2012; Mehta and Sibley, 2010; Schüler et al., 2005a; Shiozaki et al., 2009; Singh et al., 2011). It is established that actins from lower eukaryotes, such as the Apicomplexan parasites, have very low inherent stability, which is required for the effective adaptation for gliding motility (Dobrowolski et al., 1997; Hirono et al., 1989; Sahoo et al., 2006; Schüler et al., 2005b; Skillman et al., 2011; Skillman et al., 2013). Also these actins can have very different characteristics compared to eukaryotic and bacterial actins. As one peculiar example, T. gondii actin exhibits isodesmic polymerization without critical concentration and nucleation phase (Skillman et al., 2013). In conclusion, it seems that ADF/cofilins are evolutionary adapted to the special features of the actin cytoskeleton in different organisms.

Since the nucleotide binding cleft is not included in the direct binding site of the ADF$\mathrm{H}$ domain, it indicates that the binding of ADF-H domain induces allosteric conformational changes which propagate from its direct binding site towards the nucleotide binding cleft of G-actin. The high resolution structure of the Twf-C-G-actin complex shows that the nucleotide binding cleft of actin is in a closed state (Paavilainen et al., 2008). In parallel, in the case of profilin that enhances nucleotide exchange the cleft is in an open state (Schutt et al., 1993). In support of this, proteolytic footprinting and fluorescence spectroscopy showed that $S$. cerevisiae cofilin binding induces long range allosteric effects in the monomer, which results in conformational changes near the nucleotide binding cleft leading to the closure of the cleft (Kamal et al., 2007). Consistently, fluorescence quenching of the G-actin bound $\varepsilon$ ATP revealed that the accessibility of the nucleotide is antagonistically regulated by ADF/cofilins and profilin. The binding of $S$. cerevisiae cofilin decreased, while the binding of profilin increased the accessibility of the bound nucleotide to the quencher (Kardos et al., 
2009). Temperature-dependent fluorescence resonance energy transfer measurements showed that both mouse cofilin-1 and profilin decreased the flexibility of the protein matrix in the small domain (SD1 and SD2) of actin, suggesting that this region of actin works autonomously as a rigid unit during the opening and closing of the nucleotide binding cleft (Kardos et al., 2013). The differences in the rate of the nucleotide exchange were proposed to correlate with the thermodynamic stability of actin monomers, as cofilin (chicken and mouse cofilin-1) increased the thermal stability of actin monomers, while profilin had opposite effect (Dedova et al., 2004; Kardos et al., 2013). Thus, the closed state of the cleft appears to render actin monomers to be thermodynamically more stable by increasing the global stability of the monomer structure (Pivovarova et al., 2013), providing another possible link between the function and conformation of these proteins. However, this correlation does not seem to be a general principle. Recent analysis has shown that the binding of cofilin stabilized both ATP and ADP-actin monomers, while the binding of twinfilin stabilized ADP-actin monomers and destabilized ATP-actin monomers (Pivovarova et al., 2013). Also, ADF1 from P. falciparum enhances the nucleotide exchange yet increases the thermal stability of actin monomers (Schüler et al., 2005a).

The conformational transitions of the nucleotide binding cleft on monomeric actin is thought to be the structural basis for the different effects of ABPs on the nucleotide exchange rate (Schüler et al., 2006). There is always a correlation in proteins between structural rearrangements and functional changes, although the details of these correlations are sometimes not easy to define. For ADF-H proteins one of the most important functional aspects is their effect on the nucleotide exchange rates of G-actin. Some of these proteins decrease the exchange rate with different magnitudes, while others can even increase it. In the current nomenclature the faster exchange rates are attributed to more open, while slower rates to more compact, often called close, conformation of the nucleotide binding pocket. The characterizations as open and close came from the investigations of the 3D crystal structures of G-actin and the related protein complexes, where the small and large domains of actin appeared to be more distant or closer to each other, respectively. While these specifications (open and close) are reasonable and plausible, one needs to be careful when considering their real and physically veritable meaning. One important aspect to keep in mind is that 3D structures show the most probable mass distribution of the proteins and are not sensitive to their motions and transitions. The structures are packed and thus the 3D atomic resolutions are static. Apart from the changes in the average conformational state of actin, dynamic factors can also contribute substantially to the manifestation of various (faster and slower) nucleotide exchange rates. The large and small domains are known to produce scissor-like motion. This motion has a certain amplitude and frequency, which is characteristic for the actual conformational distribution of actin. Both of these parameters can influence the nucleotide exchange rates even if the average conformation of the two domains remains unchanged. In a simple model one assumes that larger amplitudes can distort more the optimal conformation for nucleotide binding, and thus should decrease the momentary affinity of actin for the nucleotide. As under usual conditions the nucleotide exchange rate is governed kinetically by the dissociation of the bound nucleotide, larger amplitudes are expected to increase the nucleotide exchange rate. The frequency may have a more complicated effect on the exchange rate. The relationship between the time range of the dissociation of the nucleotide and the 
period time of the protein's segmental motion around the entrance of the nucleotide binding pocket has to be considered, as well. In conclusion, studying the different structural background for the inhibition versus stimulation of nucleotide exchange on actin monomers by ADF-H proteins would give further insights into the understanding the structural and evolutional origin of this function.

\section{SPECIFIC STRUCTURAL FEATURES OF ADF-H DOMAIN PROTEINS}

Besides considering different conformational changes in actin one has to consider the structural elements in the ADF-H domains, as well. How the specific structural characteristics of the ADF-H domain proteins can be linked to their specialized function? Existing structures of ADF-H domain proteins seem to reveal some general principles. The F-actin binding sites of yeast cofilin, yeast Abp1, mouse coactosin and the C-terminal ADF-H domain of mouse twinfilin share similar features, and they diverge from this site in mouse GMF and the Nterminal ADF-H domain of mouse twinfilin. Also, key residues in the G-actin binding interface of Abp1 and GMF are not conserved compared to the corresponding residues in ADF/cofilins and twinfilin (Quintero-Monzon et al., 2005). These can provide a structural basis for the different interactions of the ADF-H domain families with actin monomers, filaments and the Arp2/3 complex. However, functional differences can be detected not only between ADF-H domain families but even amongst different proteins in the same family. As we summarized above, ADF/cofilins from higher eukaryotes bind actin filaments, while some Apicomplexan ADF/cofilins do not. The lack of actin filament binding was proposed to result from the distortion of the F-actin binding site in P. falciparum ADF1 and T. gondii ADF compared to other ADF/cofilins. Interestingly, compared to twinfilins and most of the ADF/cofilins Euglenozoa, Ciliophora and Apicomplexa ADF/cofilins have opposite effect on the nucleotide exchange on actin monomers. These ADF/cofilins appeared after the divergence of twinfilins and ADF/cofilins, thus represent a special lineage of ADF/cofilin proteins. The structural and functional significance of their specific effects is not known yet.

Our analysis revealed that while the ADF-H domains are similar in sequence and share the same structure (61 known structures in Pfam database are highly similar), vertebrate cofilins have two specific hydrophilic loops within their structure; the first is located between the $\alpha 1$ helix and $\beta 2$ strand, while the second one is inserted between the $\beta 3$ strand and the $\alpha 2$ helix (Figure $4 A$ and $B$ ). These structural elements are completely missing from nonvertebrate ADF/cofilins (Supplemental Figure 1) and also from other ADF-H domain proteins such as human twinfilin, coactosin, GMF and drebrin (data not shown). Surface loops on globular proteins are usually evolutionary less conserved compared to the buried regions, as these regions are not responsible for the structural integrity of the domain. In vertebrate cofilins the 12 and 10 residue long loops, and especially their hydrophilic / physical character, shows similar levels of conservation as other parts of the domain (Figure 4A), which suggests that biological function is linked to the region. Surface loops with high flexibility on a globular domain can function as a short linear motif mediating protein-protein interaction. In the case of vertebrate cofilins, these two loops form one substructure unit providing a large potential binding surface on the ADF-H domain, without having a role in the structural integrity of the main domain (Figure 4C). While the loops are on the opposite side as the G- 
site of the domain (Figure 4C), a potential partner binding on this specific surface can modify the molecular function of cofilins in their complex with actin. It is also possible that without any protein partner this vertebrate-specific substructure has an effect on the whole dynamics and flexibility of the ADF-H domain, altering the main structural and functional property of the domain, compared to the cofilins in invertebrates. Experiments targeting this region, such as site-directed mutagenesis and generation of chimera ADF/cofilins (sharing vertebrate and non-vertebrate structural features) are needed to answer the question regarding the functional importance of this vertebrate-specific structural element. 


\section{CONCLUSIONS}

Although they possess the same domain fold, the functions of the different ADF-H domain proteins are diverse. The ADF-H fold can interact with monomeric and/or filamentous actin as well as with the Arp2/3 complex, and they prefer to form a complex with the ADPstate of G-actin, F-actin or the Arp2 subunit of the Arp2/3 complex. The structural and evolutional origin of the versatile adaptation of ADF-H domain proteins for diverse functioning in the regulation of the actin cytoskeleton remains to be elucidated. Differences in the conserved sequence could endow the ADF-H domain proteins with specific activities even within the same protein family. These elements could confer special conformational dynamic features to the ADF-H domain and/or scaffold to recruit specific binding partners. Further studies addressing the importance of these specific sequence elements will certainly contribute to the understanding of the molecular and evolutional origin of the functional diversity of the ADF-H domains. Also, true understanding of the physico-chemical properties of ADF-H domain proteins underlying their biological functions requires investigations in homologous systems. The functional differences in the ADF/cofilin family also emphasize that functional classification of proteins on the basis of nomenclature can be misleading. We propose that a revision and a novel categorization are needed in the field of proteins called "ADF/cofilins", as they differ not only on the functional but structural level, as well. Based on the name, these proteins are traditionally handled as one functional class, although at least the vertebrate and invertebrate cofilins, as our sequence analysis shows, belong to different structural and functional categories. The description of these domains also needs some revision, e.g. in Pfam, which is considered to be one of the most reliable domain databases, the seed sequence alignment is shifted in the case of the N-terminal end of human cofilin-1, which results in a less descriptive domain definition for the ADF-H domain. 


\section{TABLES}

Table 1. Canonical physico-chemical properties of ADF-H domain proteins.

Canonical features of the interactions of ADF-H domains with actin monomers, filaments and the Arp $2 / 3$ complex.

\begin{tabular}{|c|c|c|c|c|c|c|}
\hline \multirow{2}{*}{$\begin{array}{l}\text { PROTEIN } \\
\text { FAMILY }\end{array}$} & \multirow{2}{*}{$\begin{array}{l}\text { \# ADF-H } \\
\text { DOMAINS }\end{array}$} & \multicolumn{4}{|c|}{ CANONICAL FEATURES } & \multirow{2}{*}{ EXCEPTIONS } \\
\hline & & G-actin & F-actin & $\begin{array}{l}\text { Arp2/3 } \\
\text { complex }\end{array}$ & functional outcome & \\
\hline ADF/cofilin & 1 & $\begin{array}{l}\text { YES } \\
(1: 1, A D P)^{1}\end{array}$ & $\begin{array}{l}\text { YES } \\
\text { ADP }\end{array}$ & NO & $\begin{array}{l}\text { - inhibition of nucleotide exchange on } \\
\text { G-actin } \\
\text { - cooperative binding to F-actin } \\
\text { - concentration-dependent } \\
\text { stabilization/destabilization of F-actin } \\
\text { - pH-dependent F-actin } \\
\text { binding/severing }\end{array}$ & see Table 2. \\
\hline twinfilin & 2 & $\begin{array}{l}\text { YES } \\
(1: 1, A D P)^{1}\end{array}$ & NO & NO & $\begin{array}{l}\text { - inhibition of nucleotide exchange on } \\
\text { G-actin } \\
\text { - G-actin sequestration }\end{array}$ & $\begin{array}{l}\text { S. cerevisiae twinfilin1: } \\
\text { severing at } \mathrm{pH}<6.0 \\
\text { (S. cerevisiae and RbskACT) }^{2} \\
\text { Mus. musculus twinfilin1: } \\
\text { barbed end capping } \\
(\text { RbskACT) })^{2}\end{array}$ \\
\hline coactosin & 1 & NO & YES & NO & - anti-capping of F-actin & \\
\hline drebrin & 1 & NO & YES & NO & $\begin{array}{l}\text { - } \text { stabilization of F-actin } \\
\text { protection of F-actin from } \\
\text { depolymerization }\end{array}$ & \\
\hline Abp1 & 1 & NO & YES & indirect & - activation of the Arp2/3 complex & \\
\hline GMF & 1 & NO & NO & $\begin{array}{l}\text { Arp2 } \\
(1: 1, A D P)^{1}\end{array}$ & $\begin{array}{l}\text { - interfering with the activity of the } \\
\text { Arp2/3 complex } \\
\text { - severing of the branch junction }\end{array}$ & \\
\hline
\end{tabular}

${ }^{1}$ stoichiometry and preferred nucleotide state of actin ${ }^{2}$ isoform of actin

RbskACT: rabbit skeletal muscle actin 
Table 2. Characteristic features of the interactions of ADF/cofilins with actin filaments (A) and monomers (B).

The canonical and non-canonical activities are highlighted by green and red, respectively.

\begin{tabular}{|c|c|c|c|c|c|c|}
\hline \multicolumn{7}{|c|}{ (A) F-ACTIN INTERACTION } \\
\hline & $\begin{array}{l}\text { ADF/COFILIN } \\
\text { PROTEIN }\end{array}$ & $\begin{array}{l}\text { FILAMENT } \\
\text { BINDING }^{1}\end{array}$ & $\begin{array}{c}\text { DEPOLYMERIZING } \\
\text { ACTIVITY }\end{array}$ & pH SENSITIVITY ${ }^{2}$ & COOPERATIVITY & REFERENCE \\
\hline \multirow{7}{*}{ CHORDATA } & \multirow{2}{*}{$\begin{array}{l}\text { human } \\
\text { ADF destrin }\end{array}$} & \multirow{2}{*}{ YES (RbskACT) } & \multirow{2}{*}{ YES (RbskACT) } & YES (RbskACT) & \multirow{2}{*}{ YES (RbskACT) } & \multirow[t]{2}{*}{$\begin{array}{l}\text { (Chen et al., 2004; Yeoh } \\
\text { et al., 2002) }\end{array}$} \\
\hline & & & & $\mathrm{NO}$ (chickskACT) & & \\
\hline & $\begin{array}{l}\text { human } \\
\text { cofilin-1 (nm) }\end{array}$ & YES (RbskACT) & $\begin{array}{l}\text { YES (RbskACT) } \\
\text { Severing RbskACT }\end{array}$ & YES (RbskACT) & $\begin{array}{l}\text { YES } \\
\text { (human platelet > } \\
\text { RbskACT) }\end{array}$ & $\begin{array}{l}\text { (Tammana et al., 2008; } \\
\text { Yeoh et al., 2002) }\end{array}$ \\
\hline & $\begin{array}{l}\text { M. musculus } \\
\text { ADF }\end{array}$ & $\begin{array}{l}\text { YES (RbskACT, } \\
\text { platelet) }\end{array}$ & $\begin{array}{l}\text { YES (RbskACT, } \\
\text { platelet) }\end{array}$ & YES (platelet) & ND & (Vartiainen et al., 2002) \\
\hline & $\begin{array}{l}\text { M. musculus } \\
\text { cofilin-1 (nm) }\end{array}$ & $\begin{array}{l}\text { YES (RbskACT, } \\
\text { platelet) }\end{array}$ & $\begin{array}{l}\text { YES (RbskACT, } \\
\text { platelet) }\end{array}$ & $\begin{array}{l}\text { NO } \\
\text { (platelet) }\end{array}$ & $\begin{array}{l}\text { YES } \\
\text { (RbskACT, platelet) }\end{array}$ & (Vartiainen et al., 2002) \\
\hline & $\begin{array}{l}\text { M. musculus } \\
\text { cofilin-2 (m) }\end{array}$ & $\begin{array}{l}\text { YES (RbskACT, } \\
\text { platelet) }\end{array}$ & $\begin{array}{l}\text { YES (RbskACT, } \\
\text { platelet) }\end{array}$ & $\begin{array}{l}\text { NO (RbskACT, } \\
\text { platelet) }\end{array}$ & $\begin{array}{l}\text { YES (RbskACT, } \\
\text { platelet) }\end{array}$ & (Vartiainen et al., 2002) \\
\hline & $\begin{array}{l}\text { D. melanogaster } \\
\text { twinstar }\end{array}$ & ND & ND & $\mathrm{NO}$ (chickskACT) & ND & (Chen et al., 2004) \\
\hline FUNGI & $\begin{array}{l}\text { S. cerevisiae } \\
\text { cofilin }\end{array}$ & $\begin{array}{l}\text { YES (bovine beta, } S . \\
\text { cerevisiae) }\end{array}$ & $\begin{array}{l}\text { YES (bovine beta, } S \text {. } \\
\text { cerevisiae) }\end{array}$ & $\begin{array}{l}\text { YES (chickskACT, } \\
\text { bovine beta) }\end{array}$ & $\mathrm{NO}$ (yeast, RbskACT) & $\begin{array}{l}\text { (Balcer et al., 2003; Chen } \\
\text { et al., 2004; Grintsevich } \\
\text { et al., 2008; Lappalainen } \\
\text { et al., 1997; Schüler et al., } \\
\text { 2005a) }\end{array}$ \\
\hline \multirow{2}{*}{ AMOEBOZOA } & \multirow{2}{*}{$\begin{array}{l}\text { A. castellanii } \\
\text { actophorin }\end{array}$} & \multirow{2}{*}{$\begin{array}{l}\text { YES (RbskACT, } \\
\text { Acanthamoeba) }\end{array}$} & \multirow{2}{*}{$\begin{array}{l}\text { YES (RbskACT, } \\
\text { Acanthamoeba }\end{array}$} & \multirow{2}{*}{$\begin{array}{l}\mathrm{NO} \text { (RbskACT, } \\
\text { chickskACT) }\end{array}$} & YES (RbskACT) & \multirow{2}{*}{$\begin{array}{l}\text { (Blanchoin and Pollard, } \\
\text { 1998, 1999; Chen et al., } \\
\text { 2004; Maciver and } \\
\text { Weeds, 1994) }\end{array}$} \\
\hline & & & & & & \\
\hline \multirow{3}{*}{ EUGLENOZOA } & \multirow{2}{*}{$\begin{array}{l}\text { L. donovani } \\
\text { rLdCof }\end{array}$} & YES (LdACT) & \multirow{2}{*}{$\begin{array}{l}\text { YES (LdACT, } \\
\text { RbskACT) } \\
\text { very weak severing of } \\
\text { RbskACT }\end{array}$} & \multirow[b]{2}{*}{ NO (RbskACT) } & \multirow[b]{2}{*}{ ND } & \multirow{2}{*}{$\begin{array}{l}\text { (Kumar et al., 2012; } \\
\text { Pathak et al., 2010; } \\
\text { Tammana et al., 2008) }\end{array}$} \\
\hline & & $\mathrm{NO}$ (RbskACT) & & & & \\
\hline & $\begin{array}{l}\text { T. brucei } \\
\text { TbCof }\end{array}$ & $\mathrm{NO}$ (RbskACT) & YES (RbskACT) & NO (RbskACT) & ND & (Dai et al., 2013) \\
\hline \multirow{2}{*}{ CILIOPHORA } & $\begin{array}{l}\text { T. thermophile } \\
\text { TtADF73p }\end{array}$ & YES (RbskACT) & $\begin{array}{l}\text { YES (RbskACT) } \\
\text { only when BE is } \\
\text { capped }\end{array}$ & NO (RbskACT) & ND & (Shiozaki et al., 2009) \\
\hline & $\begin{array}{l}\text { C. irritant } \\
\text { CiADF }\end{array}$ & YES (?) & YES (?) & ND & ND & (Huang et al., 2013) \\
\hline \multirow{3}{*}{ APICOMPLEXA } & $\begin{array}{l}\text { P. falciparum } \\
\text { PfADF1 }\end{array}$ & $\begin{array}{l}\mathrm{NO} \text { (bovine beta, } \\
\text { human platelet) }\end{array}$ & $\begin{array}{l}\text { YES (bovine beta, } \\
\text { human platelet) }\end{array}$ & NO (bovine beta) & ND & $\begin{array}{l}\text { (Schüler et al., 2005a; } \\
\text { Singh et al., 2011; Wong } \\
\text { et al., 2011) }\end{array}$ \\
\hline & $\begin{array}{l}\text { P. berghei } \\
\text { PbADF2 }\end{array}$ & $\begin{array}{l}\text { YES (human } \\
\text { platelet) }\end{array}$ & $\mathrm{NO}$ (human platelet) & ND & ND & (Singh et al., 2011) \\
\hline & $\begin{array}{l}\text { T. gondii } \\
\text { TgADF }\end{array}$ & $\begin{array}{l}\text { NO (RbskACT: very } \\
\text { little), TgACT1) }\end{array}$ & $\begin{array}{l}\text { YES (RbskACT, } \\
\text { TgACT1) } \\
\text { very weak severing of } \\
\text { RbskACT }\end{array}$ & $\mathrm{NO}$ (RbskACT) & ND & $\begin{array}{l}\text { (Mehta and Sibley, 2010; } \\
\text { Yadav et al., 2011) }\end{array}$ \\
\hline
\end{tabular}




\section{(B) G-ACTIN INTERACTION}

\begin{tabular}{|c|c|c|c|c|}
\hline & ADF/COFILIN PROTEIN & $\begin{array}{l}\text { MONOMER BINDING / } \\
\text { PREFERRED NUCLEOTIDE STATE }\end{array}$ & EFFECT ON NUCLEOTIDE EXCHANGE & REFERENCE \\
\hline \multirow{6}{*}{ CHORDATA } & $\begin{array}{l}\text { human } \\
\text { ADF destrin }\end{array}$ & YES/ADP (RbskACT) & inhibition (RbskACT) & $\begin{array}{l}\text { (Chen et al., 2004; Yeoh et } \\
\text { al., 2002) }\end{array}$ \\
\hline & $\begin{array}{l}\text { human } \\
\text { cofilin } 1 \text { (nm) }\end{array}$ & YES/ADP (RbskACT) & inhibition (RbskACT) & $\begin{array}{l}\text { (Tammana et al., 2008; } \\
\text { Yeoh et al., 2002) }\end{array}$ \\
\hline & $\begin{array}{l}\text { M. musculus } \\
\text { ADF }\end{array}$ & YES/ADP (RbskACT) & ND & (Vartiainen et al., 2002) \\
\hline & $\begin{array}{l}\text { M. musculus } \\
\text { cofilin } 1 \text { (nm) }\end{array}$ & YES/ADP (RbskACT) & ND & (Vartiainen et al., 2002) \\
\hline & $\begin{array}{l}\text { M. musculus } \\
\text { cofilin } 2(\mathrm{~m})\end{array}$ & YES/ADP (RbSKACT) & ND & (Vartiainen et al., 2002) \\
\hline & $\begin{array}{l}\text { D. melanogaster } \\
\text { twinstar }\end{array}$ & YES/ADP (chickskACT) & ND & (Chen et al., 2004) \\
\hline FUNGI & $\begin{array}{l}\text { S. cerevisiae } \\
\text { cofilin }\end{array}$ & YES/ADP (bovine beta, S. cerevisiae) & inhibition (bovine beta, S. cerevisiae) & $\begin{array}{l}\text { (Balcer et al., 2003; Chen } \\
\text { et al., 2004; Grintsevich et } \\
\text { al., 2008; Lappalainen et } \\
\text { al., 1997; Schüler et al., } \\
\text { 2005a) }\end{array}$ \\
\hline AMOEBOZOA & $\begin{array}{l}\text { A. castellanii } \\
\text { actophorin }\end{array}$ & YES/ADP (chickskACT, RbskACT) & ND & $\begin{array}{l}\text { (Blanchoin and Pollard, } \\
\text { 1998, 1999; Chen et al., } \\
\text { 2004; Maciver and Weeds, } \\
\text { 1994) }\end{array}$ \\
\hline \multirow{2}{*}{ EUGLENOZOA } & $\begin{array}{l}\text { L. donovani } \\
\text { rLdCof }\end{array}$ & YES/ADP (RbskACT, LdACT) & stimulation (RbskACT) & $\begin{array}{l}\text { (Kumar et al., 2012; } \\
\text { Pathak et al., 2010; } \\
\text { Tammana et al., 2008) }\end{array}$ \\
\hline & $\begin{array}{l}\text { T. brucei } \\
\text { TbCof }\end{array}$ & YES/ADP (RbskACT) & ND & (Dai et al., 2013) \\
\hline \multirow{2}{*}{ CILIOPHORA } & $\begin{array}{l}\text { T. thermophile } \\
\text { TtADF73p }\end{array}$ & YES/ADP (RbskACT) & stimulation (RbskACT) & (Shiozaki et al., 2009) \\
\hline & $\begin{array}{l}\text { C. irritant } \\
\text { CiADF }\end{array}$ & ND & ND & (Huang et al., 2013) \\
\hline \multirow{4}{*}{ APICOMPLEXA } & $\begin{array}{l}\text { P. falciparum } \\
\text { PfADF1 }\end{array}$ & $\begin{array}{l}\text { YES/ADP (human platelet, bovine beta, } \\
\text { PfACT) }\end{array}$ & $\begin{array}{l}\text { stimulation (human platelet, bovine } \\
\text { beta, PfACT) }\end{array}$ & $\begin{array}{l}\text { (Schüler et al., 2005a; } \\
\text { Singh et al., 2011) }\end{array}$ \\
\hline & $\begin{array}{l}\text { P. berghei } \\
\text { PbADF2 }\end{array}$ & YES/? (human platelet) & stimulation (human platelet) & (Singh et al., 2011) \\
\hline & \multirow{2}{*}{$\begin{array}{l}\text { T. gondii } \\
\text { TgADF }\end{array}$} & \multirow[t]{2}{*}{ YES/? (RbskACT, TgACT) } & $\begin{array}{l}\text { stimulation at low concentrations }(<1: 1) \\
\text { (RbskACT, TgACT) }\end{array}$ & \multirow{2}{*}{$\begin{array}{l}\text { (Mehta and Sibley, 2010; } \\
\text { Yadav et al., 2011) }\end{array}$} \\
\hline & & & $\begin{array}{l}\text { inhibition at high concentration (> 1:1) } \\
\text { (RbskACT, TgACT) }\end{array}$ & \\
\hline
\end{tabular}

${ }^{1}$ measured in co-sedimentation assay

${ }^{2}$ at least 2 fold increase in the depolymerizing activity measured at $\mathrm{pH} 7.8$ and 6.8

nm: non-muscle; m: muscle; RbskACT: rabbit skeletal muscle actin; chickskACT: chicken skeletal muscle actin; Ld: Leishmania donovani; Tb: Tetrahymena brucei, Tt: Tetrahymena thermophile; $\mathrm{Ci}$ : Cryptocaryon irritant; Pf: Plasmodium falciparum; $\mathrm{Pb}$ : Plasmodium berghei; Tg: Toxoplasma gondii 


\section{FIGURE LEGENDS}

\section{Figure 1. Interactions of the ADF-H domain with G-actin.}

(A) Atomic structure of the actin monomer with bound nucleotide (red) (PDB: 3DAW). The subdomains (SD) are indicated by numbers. Red arrow shows the nucleotide binding cleft between SD2 and SD4.

(B) Atomic structure of the C-terminal ADF-H domain of twinfilin (green) in complex with rabbit $\alpha$-skeletal actin monomer (gray) (PDB: 3DAW) (Paavilainen et al., 2008). The binding surface of the ADF-H domain (G-site) is highlighted by orange on both twinfilin and the actin monomer. SD1-4 denote the subdomains of actin. The structures of the ADF-H domain of twinfilin show relative vertical $180^{\circ}$ orientations to each other on the left and right panel, respectively.

\section{Figure 2. Interactions of the ADF-H domain with F-actin.}

(A) Structural model of the actin filament (light and dark blue) with bound ADF-H domains of human cofilin-2 (green) (PDB: 3J0S) (Galkin et al., 2011). The two single-stranded lefthanded helices are colored by light or dark blue, respectively. The double-stranded righthanded helix is assembled by alternating light and dark blue subunits. The region highlighted by the dotted rectangle is enlarged on panel (B).

(B) Two adjacent actin subunits (gray) in contact with cofilin (green) was extracted from the atomic structure of human cofilin-2 decorated rabbit $\alpha$-skeletal actin filament (PDB: 3JOS) (Galkin et al., 2011). The cofilin binding surfaces are orange and red on the upper (gray) and lower (light orange) actin subunits, respectively. The G- and the F-sites on cofilin are highlighted in orange and red, respectively (Galkin et al., 2011). SD1-4 denote the subdomains of actin. The structures of the ADF-H domain of human cofilin-2 show relative vertical $180^{\circ}$ orientations to each other on the left and right panel, respectively.

\section{Figure 3. Regulation of actin dynamics by ADF-H domain proteins.}

Spontaneous treadmilling of actin filaments (highlighted by gray box) is driven by the preferential incorporation of ATP-G-actin at the barbed end (BE), followed by ATP hydrolysis and phosphate-release $(\mathrm{Pi})$ in the filament, the dissociation of ADP-actin subunits from the pointed end (PE) and the subsequent exchange of the bound ADP to ATP in the actin monomers. Different ADF-H domain proteins affect different aspects of actin dynamics. Their effects can be direct by interacting with actin monomers and/or filaments or indirect by influencing the activity of the Arp $2 / 3$ complex. Differences from the canonical ADF-H domain protein activities are underlined. For more detailed explanation see the text.

Figure 4. Specific sequential and structural modules in vertebrate cofilins.

(A) Sequence alignment of vertebrate cofilins shows high conservation within the ADF-H domain, involving the vertebrate specific loop regions by highlighted red. Pfam IDs and source organisms are given.

(B) Superimposed structures of human (light brown) and yeast (light blue) cofilins (UniProt accession numbers: P23528, Q03048; PDB IDs: 1CFY, 1Q8X) show high structural identity 
in the main ADF-H domain structure, but a significant difference in the region of vertebratespecific loops (red). The two figures show relative vertical $90^{\circ}$ orientations to each other.

(C) Surface of the ADF-H domain of human cofilin-1. The potential binding surface formed by the vertebrate-specific loops is highlighted by red, the G-site derived from the crystal structure of the twinfilin-actin monomer is highlighted by blue. 


\section{ACKNOWLEDGMENTS}

This study was supported by grants from the Hungarian Science Foundation (OTKA) Grants K77840 and NN107776 (to MNy); PD83648 and K109689 (to BB), grants from the Hungarian National Office for Research and Technology (GVOP grants GVOP-3.2.1.-200404-0190/3.0 and GVOP-3.2.1.-2004-04-0228/3.0 (to MNy)) and from the National Innovation Office "Baross Gábor" Program (REG-DD-09-1-2009-0009 Tirfm_09 (to BB)) and by the Grant of PTE ÁOK-KA-2013/1 (to GH). This work was also supported by 'Science, Please! Research Team on Innovation' (SROP-4.2.2/08/1/2008-0011) program. 


\section{REFERENCES}

AIHARA, T., ODA, T., 2013. COOPERATIVE AND NON-COOPERATIVE CONFORMATIONAL CHANGES OF F-ACTIN INDUCED BY COFILIN. BIOCHEM BIOPHYS RES COMMUN 435, 229-233.

ANDRIANANTOANDRO, E., POLLARD, T.D., 2006. MECHANISM OF ACTIN FILAMENT TURNOVER BY SEVERING AND NUCLEATION AT DIFFERENT CONCENTRATIONS OF ADF/COFILIN. MOL CELL 24, 1323.

BALCER, H.I., GOODMAN, A.L., RODAL, A.A., SMITH, E., KUGLER, J., HEUSER, J.E., GOODE, B.L., 2003. COORDINATED REGULATION OF ACTIN FILAMENT TURNOVER BY A HIGH-MOLECULARWEIGHT SRV2/CAP COMPLEX, COFILIN, PROFILIN, AND AIP1. CURR BIOL 13, 2159-2169.

BAMBURG, J.R., HARRIS, H.E., WEEDS, A.G., 1980. PARTIAL PURIFICATION AND CHARACTERIZATION OF AN ACTIN DEPOLYMERIZING FACTOR FROM BRAIN. FEBS LETT 121, 178182.

BELMONT, L.D., ORLOVA, A., DRUBIN, D.G., EGELMAN, E.H., 1999. A CHANGE IN ACTIN CONFORMATION ASSOCIATED WITH FILAMENT INSTABILITY AFTER PI RELEASE. PROC NATL ACAD SCI U S A 96, 29-34.

BENCHAAR, S.A., XIE, Y., PHILLIPS, M., LOO, R.R., GALKIN, V.E., ORLOVA, A., THEVIS, M., MUHLRAD, A., ALMO, S.C., LOO, J.A., EGELMAN, E.H., REISLER, E., 2007. MAPPING THE INTERACTION OF COFILIN WITH SUBDOMAIN 2 ON ACTIN. BIOCHEMISTRY 46, 225-233.

BERNSTEIN, B.W., BAMBURG, J.R., 2010. ADF/COFILIN: A FUNCTIONAL NODE IN CELL BIOLOGY. TRENDS CELL BIOL 20, 187-195.

BLANCHOIN, L., POLLARD, T.D., 1998. INTERACTION OF ACTIN MONOMERS WITH ACANTHAMOEBA ACTOPHORIN (ADF/COFILIN) AND PROFILIN. J BIOL CHEM 273, 25106-25111.

BLANCHOIN, L., POLLARD, T.D., 1999. MECHANISM OF INTERACTION OF ACANTHAMOEBA ACTOPHORIN (ADF/COFILIN) WITH ACTIN FILAMENTS. J BIOL CHEM 274, 15538-15546.

BOBKOV, A.A., MUHLRAD, A., KOKABI, K., VOROBIEV, S., ALMO, S.C., REISLER, E., 2002. STRUCTURAL EFFECTS OF COFILIN ON LONGITUDINAL CONTACTS IN F-ACTIN. J MOL BIOL 323, 739750.

BOBKOV, A.A., MUHLRAD, A., PAVLOV, D.A., KOKABI, K., YILMAZ, A., REISLER, E., 2006. COOPERATIVE EFFECTS OF COFILIN (ADF) ON ACTIN STRUCTURE SUGGEST ALLOSTERIC MECHANISM OF COFILIN FUNCTION. J MOL BIOL 356, 325-334.

BOCZKOWSKA, M., REBOWSKI, G., DOMINGUEZ, R., 2013. GMF INTERACTS WITH ARP2/3 COMPLEX IN A NUCLEOTIDE STATE-DEPENDENT MANNER. J BIOL CHEM.

CARLIER, M.F., LAURENT, V., SANTOLINI, J., MELKI, R., DIDRY, D., XIA, G.X., HONG, Y., CHUA, N.H., PANTALONI, D., 1997. ACTIN DEPOLYMERIZING FACTOR (ADF/COFILIN) ENHANCES THE RATE OF FILAMENT TURNOVER: IMPLICATION IN ACTIN-BASED MOTILITY. J CELL BIOL 136, 1307-1322.

CARLIER, M.F., PANTALONI, D., EVANS, J.A., LAMBOOY, P.K., KORN, E.D., WEBB, M.R., 1988. THE HYDROLYSIS OF ATP THAT ACCOMPANIES ACTIN POLYMERIZATION IS ESSENTIALLY IRREVERSIBLE. FEBS LETT 235, 211-214.

CARLIER, M.F., PANTALONI, D., KORN, E.D., 1984. EVIDENCE FOR AN ATP CAP AT THE ENDS OF ACTIN FILAMENTS AND ITS REGULATION OF THE F-ACTIN STEADY STATE. J BIOL CHEM 259, 99839986.

CARLIER, M.F., PANTALONI, D., KORN, E.D., 1987. THE MECHANISMS OF ATP HYDROLYSIS ACCOMPANYING THE POLYMERIZATION OF MG-ACTIN AND CA-ACTIN. J BIOL CHEM 262, 30523059.

CASTANO, E., PHILIMONENKo, V.V., KAHLE, M., FUKALOVA, J., KALENDOVA, A., YILDIRIM, S., DZIJAK, R., DINGOVA-KRASNA, H., HOZAK, P., 2010. ACTIN COMPLEXES IN THE CELL NUCLEUS: NEW STONES IN AN OLD FIELD. HISTOCHEMISTRY AND CELL BIOLOGY 133, 607-626.

CHAN, C., BELTZNER, C.C., POLLARD, T.D., 2009. COFILIN DISSOCIATES ARP2/3 COMPLEX AND BRANCHES FROM ACTIN FILAMENTS. CURR BIOL 19, 537-545. 
CHAUDHRY, F., BREITSPRECHER, D., LITTLE, K., SHAROV, G., SOKOLOVA, O., GOODE, B.L., 2013. SRV2/CYCLASE-ASSOCIATED PROTEIN FORMS HEXAMERIC SHURIKENS THAT DIRECTLY CATALYZE ACTIN FILAMENT SEVERING BY COFILIN. MOL BIOL CELL 24, 31-41.

CHAUDHRY, F., GUERIN, C., VON WITSCH, M., BLANCHOIN, L., STAIGER, C.J., 2007. IDENTIFICATION OF ARABIDOPSIS CYCLASE-ASSOCIATED PROTEIN 1 AS THE FIRST NUCLEOTIDE EXCHANGE FACTOR FOR PLANT ACTIN. MOL BIOL CELL 18, 3002-3014.

CHAUDHRY, F., LITTLE, K., TALARICO, L., QUINTERO-MONZON, O., GOODE, B.L., 2010. A CENTRAL ROLE FOR THE WH2 DOMAIN OF SRV2/CAP IN RECHARGING ACTIN MONOMERS TO DRIVE ACTIN TURNOVER IN VITRO AND IN VIVO. CYTOSKELETON 67, 120-133.

CHEN, H., BERNSTEIN, B.W., SNEIDER, J.M., BOYLE, J.A., MINAMIDE, L.S., BAMBURG, J.R., 2004. IN VITRO ACTIVITY DIFFERENCES BETWEEN PROTEINS OF THE ADF/COFILIN FAMILY DEFINE TWO DISTINCT SUBGROUPS. BIOCHEMISTRY 43, 7127-7142.

CHEREAU, D., KERFF, F., GRACEFFA, P., GRABAREK, Z., LANGSETMO, K., DOMINGUEZ, R., 2005. ACTIN-BOUND STRUCTURES OF WISKOTT-ALDRICH SYNDROME PROTEIN (WASP)-HOMOLOGY DOMAIN 2 AND THE IMPLICATIONS FOR FILAMENT ASSEMBLY. PROC NATL ACAD SCI U S A 102, 16644-16649.

CHHABRA, D., DOS REMEDIOS, C.G., 2005. COFILIN, ACTIN AND THEIR COMPLEX OBSERVED IN VIVO USING FLUORESCENCE RESONANCE ENERGY TRANSFER. BIOPHYS J 89, 1902-1908.

DAI, K., LIAO, S., ZHANG, J., ZHANG, X., TU, X., 2013. STRUCTURAL AND FUNCTIONAL INSIGHT INTO ADF/COFILIN FROM TRYPANOSOMA BRUCEI. PLOS ONE 8, E53639.

DE HOSTOS, E.L., BRADTKE, B., LOTTSPEICH, F., GERISCH, G., 1993. COACTOSIN, A 17 KDA F-ACTIN BINDING PROTEIN FROM DICTYOSTELIUM DISCOIDEUM. CELL MOTIL CYTOSKELETON 26, 181-191.

DE LA CRUZ, E.M., 2005. COFILIN BINDING TO MUSCLE AND NON-MUSCLE ACTIN FILAMENTS: ISOFORM-DEPENDENT COOPERATIVE INTERACTIONS. J MOL BIOL 346, 557-564.

DEDOVA, I.V., NIKOLAEVA, O.P., MIKHAILOVA, V.V., DOS REMEDIOS, C.G., LEVITSKY, D.I., 2004. TWO OPPOSITE EFFECTS OF COFILIN ON THE THERMAL UNFOLDING OF F-ACTIN: A DIFFERENTIAL SCANNING CALORIMETRIC STUDY. BIOPHYS CHEM 110, 119-128.

DIDRY, D., CARLIER, M.F., PANTALONI, D., 1998. SYNERGY BETWEEN ACTIN DEPOLYMERIZING FACTOR/COFILIN AND PROFILIN IN INCREASING ACTIN FILAMENT TURNOVER. J BIOL CHEM 273, 25602-25611.

DOBROWOLSKI, J.M., NIESMAN, I.R., SIBLEY, L.D., 1997. ACTIN IN THE PARASITE TOXOPLASMA GONDII IS ENCODED BY A SINGLE COPY GENE, ACT1 AND EXISTS PRIMARILY IN A GLOBULAR FORM. CELL MOTIL CYTOSKELETON 37, 253-262.

ELAM, W.A., KANG, H., DE LA CRUZ, E.M., 2013. COMPETITIVE DISPLACEMENT OF COFILIN CAN PROMOTE ACTIN FILAMENT SEVERING. BIOCHEM BIOPHYS RES COMMUN.

FALCK, S., PAAVILAINEN, V.O., WEAR, M.A., GROSSMANN, J.G., COOPER, J.A., LAPPALAINEN, P., 2004. BIOLOGICAL ROLE AND STRUCTURAL MECHANISM OF TWINFILIN-CAPPING PROTEIN INTERACTION. EMBO J 23, 3010-3019.

FEDOROV, A.A., LAPPALAINEN, P., FEDOROV, E.V., DRUBIN, D.G., ALMO, S.C., 1997. STRUCTURE DETERMINATION OF YEAST COFILIN. NAT STRUCT BIOL 4, 366-369.

GALKIN, V.E., ORLOVA, A., KUDRYASHOV, D.S., SOLODUKHIN, A., REISLER, E., SCHRODER, G.F., EGELMAN, E.H., 2011. REMODELING OF ACTIN FILAMENTS BY ADF/COFILIN PROTEINS. PROC NATL ACAD SCI U S A 108, 20568-20572.

GALKIN, V.E., ORLOVA, A., LUKOYANOVA, N., WRIGGERS, W., EGELMAN, E.H., 2001. ACTIN DEPOLYMERIZING FACTOR STABILIZES AN EXISTING STATE OF F-ACTIN AND CAN CHANGE THE TILT OF F-ACTIN SUBUNITS. J CELL BIOL 153, 75-86.

GALKIN, V.E., ORLOVA, A., VANLOOCK, M.S., SHVETSOV, A., REISLER, E., EGELMAN, E.H., 2003. ADF/COFILIN USE AN INTRINSIC MODE OF F-ACTIN INSTABILITY TO DISRUPT ACTIN FILAMENTS. J CELL BIOL 163, 1057-1066.

GANDHI, M., ACHARD, V., BLANCHOIN, L., GOODE, B.L., 2009. CORONIN SWITCHES ROLES IN ACTIN DISASSEMBLY DEPENDING ON THE NUCLEOTIDE STATE OF ACTIN. MOL CELL 34, 364-374. 
GANDHI, M., SMITH, B.A., BOVELLAN, M., PAAVILAINEN, V., DAUGHERTY-CLARKE, K., GELLES, J., LAPPALAINEN, P., GOODE, B.L., 2010. GMF IS A COFILIN HOMOLOG THAT BINDS ARP2/3 COMPLEX TO STIMULATE FILAMENT DEBRANCHING AND INHIBIT ACTIN NUCLEATION. CURR BIOL 20, 861867.

GHOSH, M., SONG, X., MOUNEIMNE, G., SIDANI, M., LAWRENCE, D.S., CONDEELIS, J.S., 2004. COFILIN PROMOTES ACTIN POLYMERIZATION AND DEFINES THE DIRECTION OF CELL MOTILITY. SCIENCE 304, 743-746.

GOODE, B.L., DRUBIN, D.G., LAPPALAINEN, P., 1998. REGULATION OF THE CORTICAL ACTIN CYTOSKELETON IN BUDDING YEAST BY TWINFILIN, A UBIQUITOUS ACTIN MONOMERSEQUESTERING PROTEIN. J CELL BIOL 142, 723-733.

GOODE, B.L., RODAL, A.A., BARNES, G., DRUBIN, D.G., 2001. ACTIVATION OF THE ARP2/3 COMPLEX BY THE ACTIN FILAMENT BINDING PROTEIN ABP1P. J CELL BIOL 153, 627-634.

GORONCY, A.K., KOSHIBA, S., TOCHIO, N., TOMIZAWA, T., SATO, M., INOUE, M., WATANABE, S., HAYASHIZAKI, Y., TANAKA, A., KIGAWA, T., YOKOYAMA, S., 2009. NMR SOLUTION STRUCTURES OF ACTIN DEPOLYMERIZING FACTOR HOMOLOGY DOMAINS. PROTEIN SCI 18, 2384-2392.

GRINTSEVICH, E.E., BENCHAAR, S.A., WARSHAVIAK, D., BOONTHEUNG, P., HALGAND, F., WHITELEGGE, J.P., FAULL, K.F., LOO, R.R., SEPT, D., LOO, J.A., REISLER, E., 2008. MAPPING THE COFILIN BINDING SITE ON YEAST G-ACTIN BY CHEMICAL CROSS-LINKING. J MOL BIOL 377, 395-409.

GRINTSEVICH, E.E., GALKIN, V.E., ORLOVA, A., YTTERBERG, A.J., MIKATI, M.M., KUDRYASHOV, D.S., LOO, J.A., EGELMAN, E.H., REISLER, E., 2010. MAPPING OF DREBRIN BINDING SITE ON F-ACTIN. J MOL BIOL 398, 542-554.

HARRIS, H.E., BAMBURG, J.R., WEEDS, A.G., 1980. ACTIN FILAMENT DISASSEMBLY IN BLOOD PLASMA. FEBS LETT 121, 175-177.

helfer, E., NeVAlainen, E.M., NAUMANEN, P., ROMERO, S., DIDRY, D., PANTALONI, D., LAPPALAINEN, P., CARLIER, M.F., 2006. MAMMALIAN TWINFILIN SEQUESTERS ADP-G-ACTIN AND CAPS FILAMENT BARBED ENDS: IMPLICATIONS IN MOTILITY. EMBO J 25, 1184-1195.

HELLMAN, M., PAAVILAINEN, V.O., NAUMANEN, P., LAPPALAINEN, P., ANNILA, A., PERMI, P., 2004. SOLUTION STRUCTURE OF COACTOSIN REVEALS STRUCTURAL HOMOLOGY TO ADF/COFILIN FAMILY PROTEINS. FEBS LETT 576, 91-96.

HIRONO, M., KUMAGAI, Y., NUMATA, O., WATANABE, Y., 1989. PURIFICATION OF TETRAHYMENA ACTIN REVEALS SOME UNUSUAL PROPERTIES. PROC NATL ACAD SCI U S A 86, 75-79.

HOU, X., KATAHIRA, T., OHASHI, K., MIZUNO, K., SUGIYAMA, S., NAKAMURA, H., 2013. COACTOSIN ACCELERATES CELL DYNAMISM BY PROMOTING ACTIN POLYMERIZATION. DEV BIOL 379, 53-63.

HUANG, X., XU, Y., GUO, G., LIN, Q., YE, Z., YUAN, L., SUN, Z., NI, W., 2013. MOLECULAR CHARACTERIZATION OF AN ACTIN DEPOLYMERIZING FACTOR FROM CRYPTOCARYON IRRITANS. PARASITOLOGY 140, 561-568.

ICHETOVKIN, I., GRANT, W., CONDEELIS, J., 2002. COFILIN PRODUCES NEWLY POLYMERIZED ACTIN FILAMENTS THAT ARE PREFERRED FOR DENDRITIC NUCLEATION BY THE ARP2/3 COMPLEX. CURR BIOL 12, 79-84.

ISHIKAWA, R., HAYASHI, K., SHIRAO, T., XUE, Y., TAKAGI, T., SASAKI, Y., KOHAMA, K., 1994. DREBRIN, A DEVELOPMENT-ASSOCIATED BRAIN PROTEIN FROM RAT EMBRYO, CAUSES THE DISSOCIATION OF TROPOMYOSIN FROM ACTIN FILAMENTS. J BIOL CHEM 269, 29928-29933.

KAMAL, J.K., BENCHAAR, S.A., TAKAMOTO, K., REISLER, E., CHANCE, M.R., 2007. THREEDIMENSIONAL STRUCTURE OF COFILIN BOUND TO MONOMERIC ACTIN DERIVED BY STRUCTURAL MASS SPECTROMETRY DATA. PROC NATL ACAD SCI U S A 104, 7910-7915.

KARDOS, R., NEVALAINEN, E., NYITRAI, M., HILD, G., 2013. THE EFFECT OF ADF/COFILIN AND PROFILIN ON THE DYNAMICS OF MONOMERIC ACTIN. BIOCHIM BIOPHYS ACTA 1834, 2010-2019.

KARDOS, R., POZSONYI, K., NEVALAINEN, E., LAPPALAINEN, P., NYITRAI, M., HILD, G., 2009. THE EFFECTS OF ADF/COFILIN AND PROFILIN ON THE CONFORMATION OF THE ATP-BINDING CLEFT OF MONOMERIC ACTIN. BIOPHYS J 96, 2335-2343.

KORN, E.D., CARLIER, M.F., PANTALONI, D., 1987. ACTIN POLYMERIZATION AND ATP HYDROLYSIS. SCIENCE 238, 638-644. 
KUMAR, G., SRIVASTAVA, R., MITRA, K., SAHASRABUDDHE, A.A., GUPTA, C.M., 2012. OVEREXPRESSION OF S4D MUTANT OF LEISHMANIA DONOVANI ADF/COFILIN IMPAIRS FLAGELLUM ASSEMBLY BY AFFECTING ACTIN DYNAMICS. EUKARYOT CELL 11, 752-760.

LAPPALAINEN, P., FEDOROV, E.V., FEDOROV, A.A., ALMO, S.C., DRUBIN, D.G., 1997. ESSENTIAL FUNCTIONS AND ACTIN-BINDING SURFACES OF YEAST COFILIN REVEALED BY SYSTEMATIC MUTAGENESIS. EMBO J 16, 5520-5530.

LeONARD, S.A., GITTIS, A.G., PETRElla, E.C., POlLARD, T.D., LATTMAN, E.E., 1997. CRYSTAL STRUCTURE OF THE ACTIN-BINDING PROTEIN ACTOPHORIN FROM ACANTHAMOEBA. NAT STRUCT BIOL 4, 369-373.

LUAN, Q., NOLEN, B.J., 2013. STRUCTURAL BASIS FOR REGULATION OF ARP2/3 COMPLEX BY GMF. NAT STRUCT MOL BIOL.

MACIVER, S.K., WEEDS, A.G., 1994. ACTOPHORIN PREFERENTIALLY BINDS MONOMERIC ADP-ACTIN OVER ATP-BOUND ACTIN: CONSEQUENCES FOR CELL LOCOMOTION. FEBS LETT 347, 251-256.

MAKKONEN, M., BERTLING, E., CHEBOTAREVA, N.A., BAUM, J., LAPPALAINEN, P., 2013. MAMMALIAN AND MALARIA PARASITE CYCLASE-ASSOCIATED PROTEINS CATALYZE NUCLEOTIDE EXCHANGE ON G-ACTIN THROUGH A CONSERVED MECHANISM. J BIOL CHEM 288, 984-994.

MCCULLOUGH, B.R., BLANCHOIN, L., MARTIEL, J.L., DE LA CRUZ, E.M., 2008. COFILIN INCREASES THE BENDING FLEXIBILITY OF ACTIN FILAMENTS: IMPLICATIONS FOR SEVERING AND CELL MECHANICS. J MOL BIOL 381, 550-558.

MEHTA, S., SIBLEY, L.D., 2010. TOXOPLASMA GONDII ACTIN DEPOLYMERIZING FACTOR ACTS PRIMARILY TO SEQUESTER G-ACTIN. J BIOL CHEM 285, 6835-6847.

MIKATI, M.A., GRINTSEVICH, E.E., REISLER, E., 2013. DREBRIN-INDUCED STABILIZATION OF ACTIN FILAMENTS. J BIOL CHEM 288, 19926-19938.

MOSELEY, J.B., OKADA, K., BALCER, H.I., KOVAR, D.R., POLLARD, T.D., GOODE, B.L., 2006. TWINFILIN IS AN ACTIN-FILAMENT-SEVERING PROTEIN AND PROMOTES RAPID TURNOVER OF ACTIN STRUCTURES IN VIVO. J CELL SCI 119, 1547-1557.

MUHLRAD, A., RINGEL, I., PAVLOV, D., PEYSER, Y.M., REISLER, E., 2006. ANTAGONISTIC EFFECTS OF COFILIN, BERYLLIUM FLUORIDE COMPLEX, AND PHALLOIDIN ON SUBDOMAIN 2 AND NUCLEOTIDEBINDING CLEFT IN F-ACTIN. BIOPHYS J 91, 4490-4499.

NAKANO, K., KUWAYAMA, H., KAWASAKI, M., NUMATA, O., TAKAINE, M., 2010. GMF IS AN EVOLUTIONARILY DEVELOPED ADF/COFILIN-SUPER FAMILY PROTEIN INVOLVED IN THE ARP2/3 COMPLEX-MEDIATED ORGANIZATION OF THE ACTIN CYTOSKELETON. CYTOSKELETON 67, 373-382.

NISHIDA, E., 1985. OPPOSITE EFFECTS OF COFILIN AND PROFILIN FROM PORCINE BRAIN ON RATE OF EXCHANGE OF ACTIN-BOUND ADENOSINE 5'-TRIPHOSPHATE. BIOCHEMISTRY 24, 1160-1164.

NOMURA, K., ONO, S., 2013. ATP-DEPENDENT REGULATION OF ACTIN MONOMER-FILAMENT EQUILIBRIUM BY CYCLASE-ASSOCIATED PROTEIN AND ADF/COFILIN. BIOCHEM J 453, 249-259.

OJALA, P.J., PAAVILAINEN, V.O., VARTIAINEN, M.K., TUMA, R., WEEDS, A.G., LAPPALAINEN, P., 2002. THE TWO ADF-H DOMAINS OF TWINFILIN PLAY FUNCTIONALLY DISTINCT ROLES IN INTERACTIONS WITH ACTIN MONOMERS. MOL BIOL CELL 13, 3811-3821.

ONO, S., ABE, H., OBINATA, T., 1996. STIMULUS-DEPENDENT DISORGANIZATION OF ACTIN FILAMENTS INDUCED BY OVEREXPRESSION OF COFILIN IN C2 MYOBLASTS. CELL STRUCTURE AND FUNCTION 21, 491-499.

OSER, M., CONDEELIS, J., 2009. THE COFILIN ACTIVITY CYCLE IN LAMELLIPODIA AND INVADOPODIA. JOURNAL OF CELLULAR BIOCHEMISTRY 108, 1252-1262.

PAAVILAINEN, V.O., BERTLING, E., FALCK, S., LAPPALAINEN, P., 2004. REGULATION OF CYTOSKELETAL DYNAMICS BY ACTIN-MONOMER-BINDING PROTEINS. TRENDS CELL BIOL 14, 386394.

PAAVILAINEN, V.O., OKSANEN, E., GOLDMAN, A., LAPPALAINEN, P., 2008. STRUCTURE OF THE ACTIN-DEPOLYMERIZING FACTOR HOMOLOGY DOMAIN IN COMPLEX WITH ACTIN. J CELL BIOL 182, 51-59. 
PALMGREN, S., OJALA, P.J., WEAR, M.A., COOPER, J.A., LAPPALAINEN, P., 2001. INTERACTIONS WITH PIP2, ADP-ACTIN MONOMERS, AND CAPPING PROTEIN REGULATE THE ACTIVITY AND LOCALIZATION OF YEAST TWINFILIN. J CELL BIOL 155, 251-260.

PANTALONI, D., CARLIER, M.F., KORN, E.D., 1985. THE INTERACTION BETWEEN ATP-ACTIN AND ADP-ACTIN. A TENTATIVE MODEL FOR ACTIN POLYMERIZATION. J BIOL CHEM 260, 6572-6578.

PANTALONI, D., LE CLAINCHE, C., CARLIER, M.F., 2001. MECHANISM OF ACTIN-BASED MOTILITY. SCIENCE 292, 1502-1506.

PATHAK, P.P., PULAVARTI, S.V., JAIN, A., SAHASRABUDDHE, A.A., GUPTA, C.M., ARORA, A., 2010. SOLUTION STRUCTURE AND DYNAMICS OF ADF/COFILIN FROM LEISHMANIA DONOVANI. J STRUCT BIOL 172, 219-224.

PAVLOV, D., MUHLRAD, A., COOPER, J., WEAR, M., REISLER, E., 2007. ACTIN FILAMENT SEVERING BY COFILIN. J MOL BIOL 365, 1350-1358.

PENDLETON, A., POPE, B., WEEDS, A., KOFFER, A., 2003. LATRUNCULIN B OR ATP DEPLETION INDUCES COFILIN-DEPENDENT TRANSLOCATION OF ACTIN INTO NUCLEI OF MAST CELLS. J BIOL CHEM 278, 14394-14400.

PIVOVAROVA, A.V., CHEBOTAREVA, N.A., KREMNEVA, E.V., LAPPALAINEN, P., LEVITSKY, D.I., 2013. EFFECTS OF ACTIN-BINDING PROTEINS ON THE THERMAL STABILITY OF MONOMERIC ACTIN. BIOCHEMISTRY 52, 152-160.

POLLARD, T.D., 1986. RATE CONSTANTS FOR THE REACTIONS OF ATP- AND ADP-ACTIN WITH THE ENDS OF ACTIN FILAMENTS. J CELL BIOL 103, 2747-2754.

POLLARD, T.D., 2007. REGULATION OF ACTIN FILAMENT ASSEMBLY BY ARP2/3 COMPLEX AND FORMINS. ANNU REV BIOPHYS BIOMOL STRUCT 36, 451-477.

POLLARD, T.D., WEEDS, A.G., 1984. THE RATE CONSTANT FOR ATP HYDROLYSIS BY POLYMERIZED ACTIN. FEBS LETT 170, 94-98.

POUKKULA, M., KREMNEVA, E., SERLACHIUS, M., LAPPALAINEN, P., 2011. ACTIN-DEPOLYMERIZING FACTOR HOMOLOGY DOMAIN: A CONSERVED FOLD PERFORMING DIVERSE ROLES IN CYTOSKELETAL DYNAMICS. CYTOSKELETON 68, 471-490.

PROCHNIEWICZ, E., JANSON, N., THOMAS, D.D., DE LA CRUZ, E.M., 2005. COFILIN INCREASES THE TORSIONAL FLEXIBILITY AND DYNAMICS OF ACTIN FILAMENTS. J MOL BIOL 353, 990-1000.

PROVOST, P., DOUCET, J., STOCK, A., GERISCH, G., SAMUELSSON, B., RADMARK, O., 2001. COACTOSIN-LIKE PROTEIN, A HUMAN F-ACTIN-BINDING PROTEIN: CRITICAL ROLE OF LYSINE-75. BIOCHEM J 359, 255-263.

QUINTERO-MONZON, O., RODAL, A.A., STROKOPYTOV, B., ALMO, S.C., GOODE, B.L., 2005. STRUCTURAL AND FUNCTIONAL DISSECTION OF THE ABP1 ADFH ACTIN-BINDING DOMAIN REVEALS VERSATILE IN VIVO ADAPTER FUNCTIONS. MOL BIOL CELL 16, 3128-3139.

RENAULT, L., BUGYI, B., CARLIER, M.F., 2008. SPIRE AND CORDON-BLEU: MULTIFUNCTIONAL REGULATORS OF ACTIN DYNAMICS. TRENDS CELL BIOL 18, 494-504.

RISCA, V.I., WANG, E.B., CHAUDHURI, O., CHIA, J.J., GEISSLER, P.L., FLETCHER, D.A., 2012. ACTIN FILAMENT CURVATURE BIASES BRANCHING DIRECTION. PROC NATL ACAD SCI U S A 109, 29132918.

ROHRIG, U., GERISCH, G., MOROZOVA, L., SCHLEICHER, M., WEGNER, A., 1995. COACTOSIN INTERFERES WITH THE CAPPING OF ACTIN FILAMENTS. FEBS LETT 374, 284-286.

ROLAND, J., BERRO, J., MICHELOT, A., BLANCHOIN, L., MARTIEL, J.L., 2008. STOCHASTIC SEVERING OF ACTIN FILAMENTS BY ACTIN DEPOLYMERIZING FACTOR/COFILIN CONTROLS THE EMERGENCE OF A STEADY DYNAMICAL REGIME. BIOPHYS J 94, 2082-2094.

ROMERO, S., DIDRY, D., LARQUET, E., BOISSET, N., PANTALONI, D., CARLIER, M.F., 2007. HOW ATP HYDROLYSIS CONTROLS FILAMENT ASSEMBLY FROM PROFILIN-ACTIN: IMPLICATION FOR FORMIN PROCESSIVITY. J BIOL CHEM 282, 8435-8445.

ROSENBLATT, J., AGNEW, B.J., ABE, H., BAMBURG, J.R., MITCHISON, T.J., 1997. XENOPUS ACTIN DEPOLYMERIZING FACTOR/COFILIN (XAC) IS RESPONSIBLE FOR THE TURNOVER OF ACTIN FILAMENTS IN LISTERIA MONOCYTOGENES TAILS. J CELL BIOL 136, 1323-1332. 
ROUILLER, I., XU, X.P., AMANN, K.J., EGILE, C., NICKELL, S., NICASTRO, D., LI, R., POLLARD, T.D., VOLKMANN, N., HANEIN, D., 2008. THE STRUCTURAL BASIS OF ACTIN FILAMENT BRANCHING BY THE ARP2/3 COMPLEX. J CELL BIOL 180, 887-895.

SABLIN, E.P., DAWSON, J.F., VANLOOCK, M.S., SPUDICH, J.A., EGELMAN, E.H., FLETTERICK, R.J., 2002. HOW DOES ATP HYDROLYSIS CONTROL ACTIN'S ASSOCIATIONS? PROC NATL ACAD SCI U S A 99, 10945-10947.

SAHOO, N., BEATTY, W., HEUSER, J., SEPT, D., SIBLEY, L.D., 2006. UNUSUAL KINETIC AND STRUCTURAL PROPERTIES CONTROL RAPID ASSEMBLY AND TURNOVER OF ACTIN IN THE PARASITE TOXOPLASMA GONDII. MOL BIOL CELL 17, 895-906.

SCHUTT, C.E., MYSLIK, J.C., ROZYCKI, M.D., GOONESEKERE, N.C., LINDBERG, U., 1993. THE STRUCTURE OF CRYSTALLINE PROFILIN-BETA-ACTIN. NATURE 365, 810-816.

SCHÜLER, H., KARLSSON, R., SCHUTT, C.E., LINDBERG, U., 2006. THE CONNECTION BETWEEN ACTIN ATPASE AND POLYMERIZATION. ADVANCES IN MOLECULAR AND CELL BIOLOGY 37, 49-66.

SCHÜLER, H., MUELLER, A.K., MATUSCHEWSKI, K., 2005A. A PLASMODIUM ACTINDEPOLYMERIZING FACTOR THAT BINDS EXCLUSIVELY TO ACTIN MONOMERS. MOL BIOL CELL 16, 4013-4023.

SCHÜLER, H., MUELLER, A.K., MATUSCHEWSKI, K., 2005B. UNUSUAL PROPERTIES OF PLASMODIUM FALCIPARUM ACTIN: NEW INSIGHTS INTO MICROFILAMENT DYNAMICS OF APICOMPLEXAN PARASITES. FEBS LETT 579, 655-660.

SCHÜLER, H., NYAKERN, M., SCHUTT, C.E., LINDBERG, U., KARLSSON, R., 2000. MUTATIONAL ANALYSIS OF ARGININE 177 IN THE NUCLEOTIDE BINDING SITE OF BETA-ACTIN. EUR J BIOCHEM 267, 4054-4062.

SELDEN, L.A., KINOSIAN, H.J., ESTES, J.E., GERSHMAN, L.C., 1999. IMPACT OF PROFILIN ON ACTINBOUND NUCLEOTIDE EXCHANGE AND ACTIN POLYMERIZATION DYNAMICS. BIOCHEMISTRY 38, 2769-2778.

SHARMA, S., GRINTSEVICH, E.E., PHILLIPS, M.L., REISLER, E., GIMZEWSKI, J.K., 2011. ATOMIC FORCE MICROSCOPY REVEALS DREBRIN INDUCED REMODELING OF F-ACTIN WITH SUBNANOMETER RESOLUTION. NANO LETT 11, 825-827.

SHIOZAKI, N., NAKANO, K., TAKAINE, M., ABE, H., NUMATA, O., 2009. USUAL AND UNUSUAL BIOCHEMICAL PROPERTIES OF ADF/COFILIN-LIKE PROTEIN ADF73P IN CILIATE TETRAHYMENA THERMOPHILA. BIOCHEM BIOPHYS RES COMMUN 390, 54-59.

SINGH, B.K., SATTLER, J.M., CHATTERJEE, M., HUTTU, J., SCHULER, H., KURSULA, I., 2011. CRYSTAL STRUCTURES EXPLAIN FUNCTIONAL DIFFERENCES IN THE TWO ACTIN DEPOLYMERIZATION FACTORS OF THE MALARIA PARASITE. J BIOL CHEM 286, 28256-28264.

SKILLMAN, K.M., DIRAVIYAM, K., KHAN, A., TANG, K., SEPT, D., SIBLEY, L.D., 2011. EVOLUTIONARILY DIVERGENT, UNSTABLE FILAMENTOUS ACTIN IS ESSENTIAL FOR GLIDING MOTILITY IN APICOMPLEXAN PARASITES. PLOS PATHOG 7, E1002280.

SKILLMAN, K.M., MA, C.I., FREMONT, D.H., DIRAVIYAM, K., COOPER, J.A., SEPT, D., SIBLEY, L.D., 2013. THE UNUSUAL DYNAMICS OF PARASITE ACTIN RESULT FROM ISODESMIC POLYMERIZATION. NAT COMMUN 4, 2285.

STROKOPYTOV, B.V., FEDOROV, A., MAHONEY, N.M., KESSELS, M., DRUBIN, D.G., ALMO, S.C., 2005. PHASED TRANSLATION FUNCTION REVISITED: STRUCTURE SOLUTION OF THE COFILINHOMOLOGY DOMAIN FROM YEAST ACTIN-BINDING PROTEIN 1 USING SIX-DIMENSIONAL SEARCHES. ACTA CRYSTALLOGR D BIOL CRYSTALLOGR 61, 285-293.

SUAREZ, C., ROLAND, J., BOUJEMAA-PATERSKI, R., KANG, H., MCCULLOUGH, B.R., REYMANN, A.C., GUERIN, C., MARTIEL, J.L., DE LA CRUZ, E.M., BLANCHOIN, L., 2011. COFILIN TUNES THE NUCLEOTIDE STATE OF ACTIN FILAMENTS AND SEVERS AT BARE AND DECORATED SEGMENT BOUNDARIES. CURR BIOL 21, 862-868.

TAMMANA, T.V., SAHASRABUDDHE, A.A., MITRA, K., BAJPAI, V.K., GUPTA, C.M., 2008. ACTINDEPOLYMERIZING FACTOR, ADF/COFILIN, IS ESSENTIALLY REQUIRED IN ASSEMBLY OF LEISHMANIA FLAGELLUM. MOL MICROBIOL 70, 837-852. 
VAN RHEENEN, J., CONDEELIS, J., GLOGAUER, M., 2009. A COMMON COFILIN ACTIVITY CYCLE IN INVASIVE TUMOR CELLS AND INFLAMMATORY CELLS. J CELL SCI 122, 305-311.

VAN TROYS, M., HUYCK, L., LEYMAN, S., DHAESE, S., VANDEKERKHOVE, J., AMPE, C., 2008. INS AND OUTS OF ADF/COFILIN ACTIVITY AND REGULATION. EUR J CELL BIOL 87, 649-667.

VARTIAINEN, M.K., MUSTONEN, T., MATTILA, P.K., OJALA, P.J., THESLEFF, I., PARTANEN, J., LAPPALAINEN, P., 2002. THE THREE MOUSE ACTIN-DEPOLYMERIZING FACTOR/COFILINS EVOLVED TO FULFILL CELL-TYPE-SPECIFIC REQUIREMENTS FOR ACTIN DYNAMICS. MOL BIOL CELL 13, 183194.

VARTIAINEN, M.K., SARKKINEN, E.M., MATILAINEN, T., SALMINEN, M., LAPPALAINEN, P., 2003. MAMMALS HAVE TWO TWINFILIN ISOFORMS WHOSE SUBCELLULAR LOCALIZATIONS AND TISSUE DISTRIBUTIONS ARE DIFFERENTIALLY REGULATED. J BIOL CHEM 278, 34347-34355.

WEGNER, A., 1976. HEAD TO TAIL POLYMERIZATION OF ACTIN. J MOL BIOL 108, 139-150.

WEN, K.K., MCKANE, M., HOUTMAN, J.C., RUBENSTEIN, P.A., 2008. CONTROL OF THE ABILITY OF PROFILIN TO BIND AND FACILITATE NUCLEOTIDE EXCHANGE FROM G-ACTIN. J BIOL CHEM 283, 9444-9453.

WOLVEN, A.K., BELMONT, L.D., MAHONEY, N.M., ALMO, S.C., DRUBIN, D.G., 2000. IN VIVO IMPORTANCE OF ACTIN NUCLEOTIDE EXCHANGE CATALYZED BY PROFILIN. J CELL BIOL 150, 895904.

WONG, W., SKAU, C.T., MARAPANA, D.S., HANSSEN, E., TAYLOR, N.L., RIGLAR, D.T., ZUCCALA, E.S., ANGRISANO, F., LEWIS, H., CATIMEL, B., CLARKE, O.B., KERSHAW, N.J., PERUGINI, M.A., KOVAR, D.R., GULBIS, J.M., BAUM, J., 2011. MINIMAL REQUIREMENTS FOR ACTIN FILAMENT DISASSEMBLY REVEALED BY STRUCTURAL ANALYSIS OF MALARIA PARASITE ACTIN-DEPOLYMERIZING FACTOR 1. PROC NATL ACAD SCI U S A 108, 9869-9874.

WRIGGERS, W., TANG, J.X., AZUMA, T., MARKS, P.W., JANMEY, P.A., 1998. COFILIN AND GELSOLIN SEGMENT-1: MOLECULAR DYNAMICS SIMULATION AND BIOCHEMICAL ANALYSIS PREDICT A SIMILAR ACTIN BINDING MODE. J MOL BIOL 282, 921-932.

YADAV, R., PATHAK, P.P., SHUKLA, V.K., JAIN, A., SRIVASTAVA, S., TRIPATHI, S., KRISHNA PULAVARTI, S.V., MEHTA, S., SIBLEY, L.D., ARORA, A., 2011. SOLUTION STRUCTURE AND DYNAMICS OF ADF FROM TOXOPLASMA GONDII. J STRUCT BIOL 176, 97-111.

YAO, X., GRADE, S., WRIGGERS, W., RUBENSTEIN, P.A., 1999. HIS(73), OFTEN METHYLATED, IS AN IMPORTANT STRUCTURAL DETERMINANT FOR ACTIN. A MUTAGENIC ANALYSIS OF HIS(73) OF YEAST ACTIN. J BIOL CHEM 274, 37443-37449.

YAO, X., RUBENSTEIN, P.A., 2001. F-ACTIN-LIKE ATPASE ACTIVITY IN A POLYMERIZATIONDEFECTIVE MUTANT YEAST ACTIN (V266G/L267G). J BIOL CHEM 276, 25598-25604.

YDENBERG, C.A., PADRICK, S.B., SWEENEY, M.O., GANDHI, M., SOKOLOVA, O., GOODE, B.L., 2013. GMF SEVERS ACTIN-ARP2/3 COMPLEX BRANCH JUNCTIONS BY A COFILIN-LIKE MECHANISM. CURR BIOL 23, 1037-1045.

YEOH, S., POPE, B., MANNHERZ, H.G., WEEDS, A., 2002. DETERMINING THE DIFFERENCES IN ACTIN BINDING BY HUMAN ADF AND COFILIN. J MOL BIOL 315, 911-925. 


\section{Figure 1.}

A

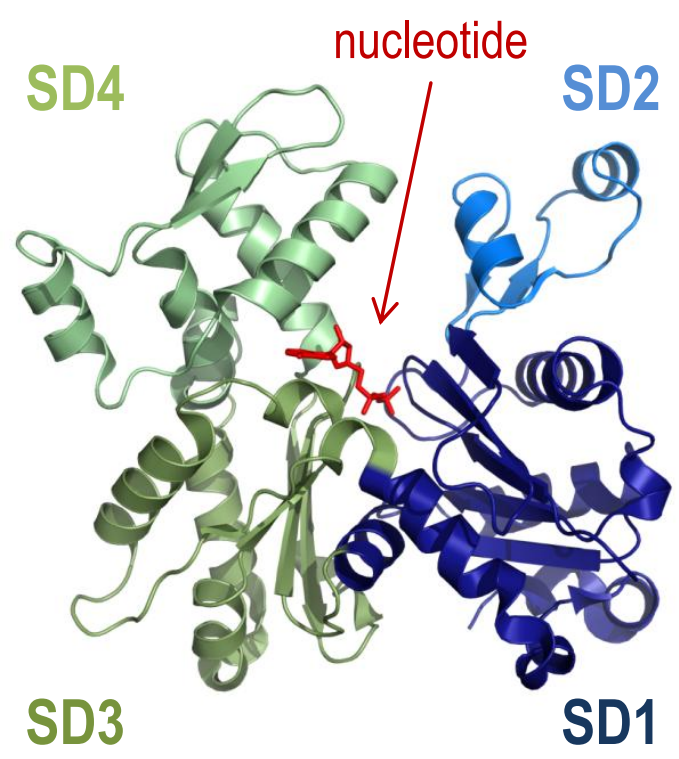

B

pointed end

G-site

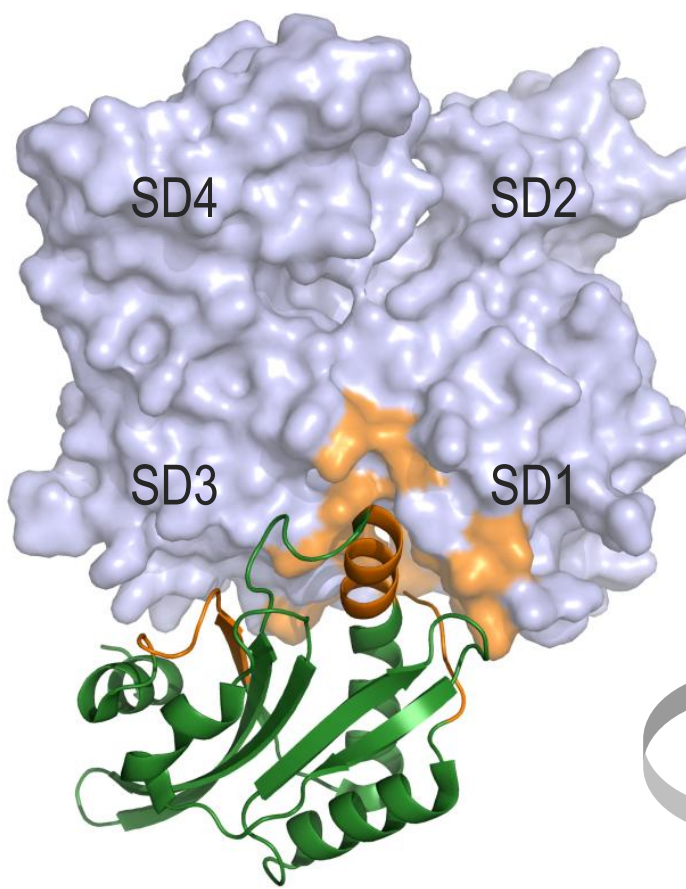

barbed end

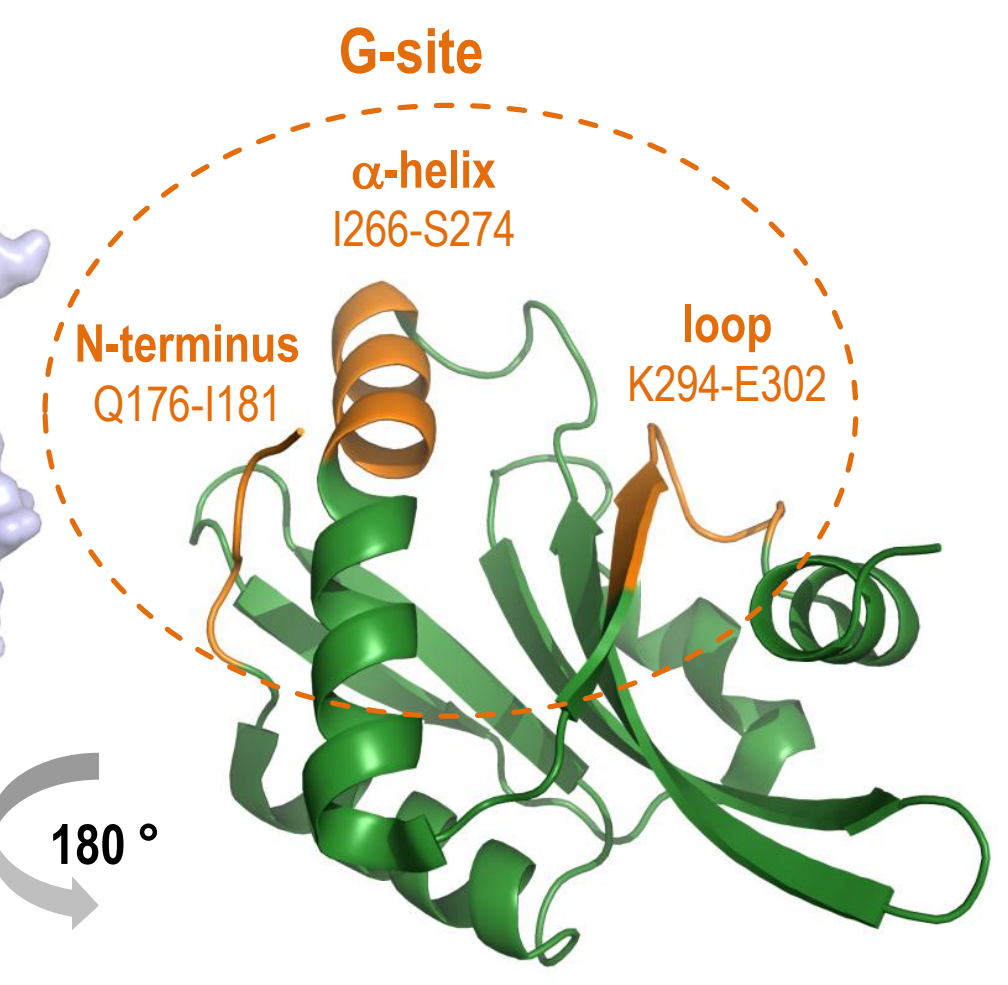


A B

pointed end
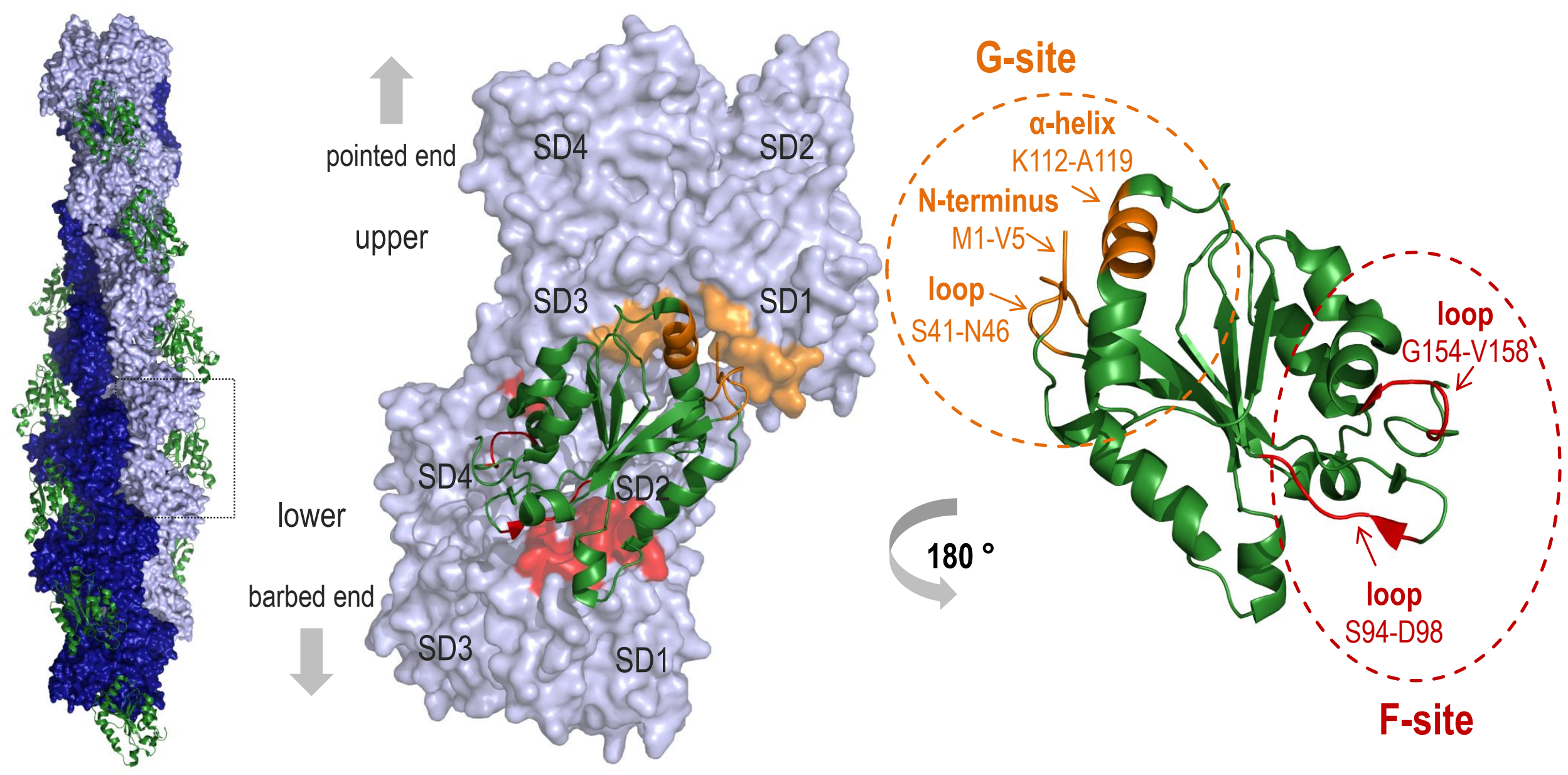

barbed end 


\section{DIRECT FILAMENT: ADF/cofilin, drebrin, coactosin, Abp1}

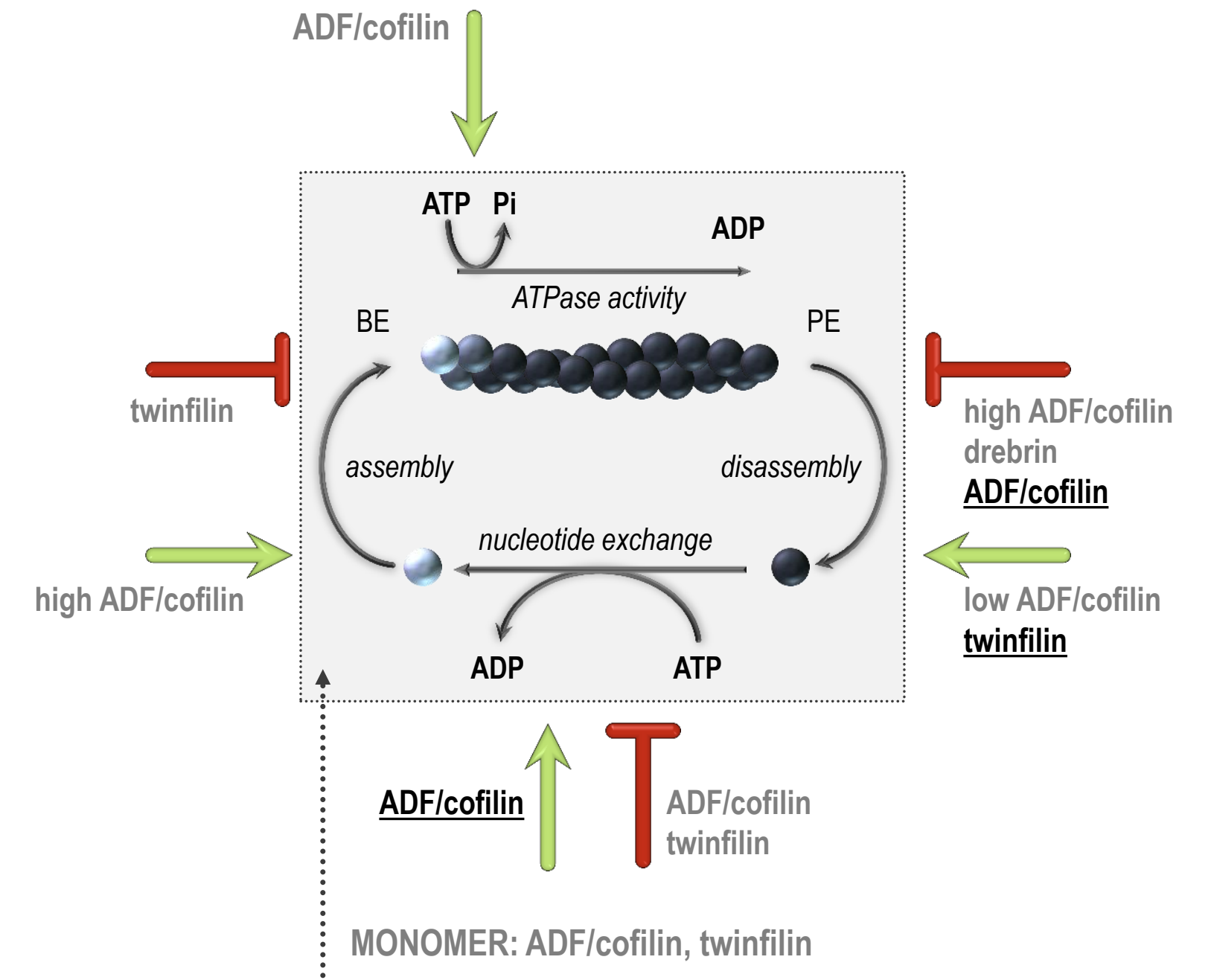

\section{INDIRECT}

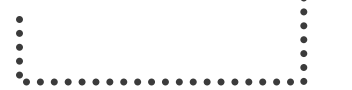

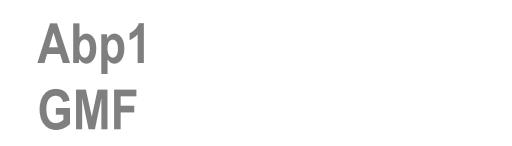

via the Arp2/3 complex

Abp1
GMF
KEY

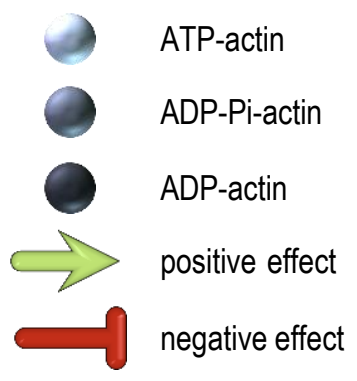


A9y281 COF2_Homo sapiens

A p21566 Cof2_Gallus gallus P45591 COF2 Mus musculus P18760 COF1_Mus musculus P23528 COF1 Homo sapiens P10668 COF1_Sus scrofa P45592 COF1_Rattus norvegicus Q6NX11 COF1_Xenopus tropicalis Q148F1 COF2 Bos taurus Q5G6V9 COF2_Sus scrofa Q6B7M7 COF1_Ovis aries P45593 COF1B_Xenopus laevis
MASGVTVNDEVI KVFNDMKVRKSSTQEEIKKRKKAVLFCLSDDKRQI IVEEAKQI LVGDI MASGVTVNDEVIKVFNDMKVRKSSTPEEIKKRKKAVLFCLSDDKKQI IVEEAKQI LVGDI MASGVTVNDEVIKVFNDMKVRKSSTQEEIKKRKKAVLFCLSDDKRQI IVEEAKQILVGDI MASGVAVSDGVIKVFNDMKVRKSSTPEEVKKRKKAVLFCLSEDKKNI I LEEGKE ILVGDV MASGVAVSDGVI KVFNDMKVRKSSTPEEVKKRKKAVLFCLSEDKKNI I LEEGKE I LVGDV MASGVAVSDGVIKVFNDMKVRKSSTPEEVKKRKKAVLFCLSEDKKNI I LEEGKEILVGDV MASGVAVSDGVI KVFNDMKVRKSSTPEEVKKRKKAVLFCLSEDKKNI I LEEGKE I LVGDV MASGVMVSDDVI KVFNDMKVRHQLSPEEAKKRKKAVVFCLSEDKKMI I LEPGKEI LQGDV MASGVTVNDEVIKVFNDMKVRKSSTQEEIKKRKKAVLFCLSDDKRQI IVEEAKQI LVGDI MASGVTVNDEVIKVFNDMKVRKSSTQEEIKKRKKAVLFCLSDDKRQI IVEEAKQILVGDI MASGVAVSDGVIKVFNDMKVRKSSTPEEVKKRKKAVLFCLSEDKKNI I LEEGKEILVGDV MASGVMVSDDVVKVFNDMKVRHQLSPEEAKKRKKAVIFCLSDDKKTI I LEPGKEI LQGDV

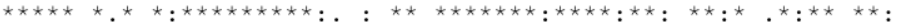
GDTVEDPYTSFVKLLPLNDCRYALYDATYETKESKKEDLVFIFWAPESAPLKSKMIYASS GDTVEDPYTAFVKLLPLNDCRYALYDATYETKESKKEDLVFIFWAPESAPLKSKMIYASS GDTVEDPYTSFVKLLPLNDCRYALYDATYETKESKKEDLVFIFWAPESAPLKSKMIYASS GQTVDDPYTTFVKMLPDKDCRYALYDATYETKESKKEDLVFIFWAPENAPLKSKMIYASS GQTVDDPYATFVKMLPDKDCRYALYDATYETKESKKEDLVFIFWAPESAPLKSKMIYASS GQTVDDPYATFVKMLPDKDCRYALYDATYETKESKKEDLVFIFWAPECAPLKSKMIYASS GQTVDDPYTTFVKMLPDKDCRYALYDATYETKESKKEDLVFIFWAPESAPLKSKMIYASS GCNVDDPYKAFVKMLPRNDCRYALYDALYETKETKKEDLVFVFWAPEEASLKSKMIYASS GDTVEDPYTSFVKLLPLNDCRYALYDATYETKESKKEDLVFIFWAPESAPLKSKMIYASS GDTVEDPYTSFVKLLPLNDCRYALYDATYETKESKKEDLVFIFWAPESAPLKSKMIYASS GQTVDDPYATFVKMLPDKDCRYALYDATYETKESKKEDLVFIFWAPECAPLKSKMIYASS GCNVEDPYKTFVKMLPRNDCRYALYDALYETKETKKEDLVFVFWAPEEASLKSKMIYASS

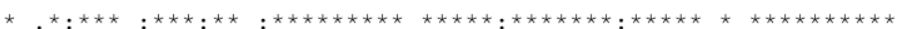

KDAIKKKFTGIKHEWQVNGLDDIKDRSTLGEKLGGNVVVSLEGKPL-- 166 KDAIKKKFTGIKHEWQVNGLDDIKDRSTLGEKLGGNVVVSLEGKPL-- 166 KDAIKKKFTGIKHEWQVNGLDDIKDRSTLGEKLGGSVVVSLEGKPL-- 166 KDAIKKKLTGIKHELQANCYEEVKDRCTLAEKLGGSAVISLEGKPL-- 166 KDAIKKKLTGIKHELQANCYEEVKDRCTLAEKLGGSAVISLEGKPL-- 166 KDAIKKKLTGIKHELQANCYEEVKDRCTLAEKLGGSAVISLEGKPL-- 166 KDAIKKKLTGIKHELQANCYEEVKDRCTLAEKLGGSAVISLEGKPL-- 166 KDAIKKRFPGIKHEWQTNTEEDINDPCNLAEKLGGSTVISLEGKTLKS 168 KDAIKKKFTGIKHEWQVNGLDDIKDRSTLGEKLGGNVVVSLEGKPL-- 166 KDAIKKKFTGIKHEWQVNGLDDIKDRSTLGEKLGGNVVVSLEGKPL-- 166 KDAIKKKLTGIKHELQANCYEEVKDRCTLAEKLGGSAVISLEGKPL-- 166 KDAIRKRFTGIKHEWQTNTYDDINDPCNLADKLGGNTVVSLEGKSLRS 168

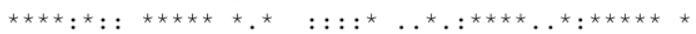

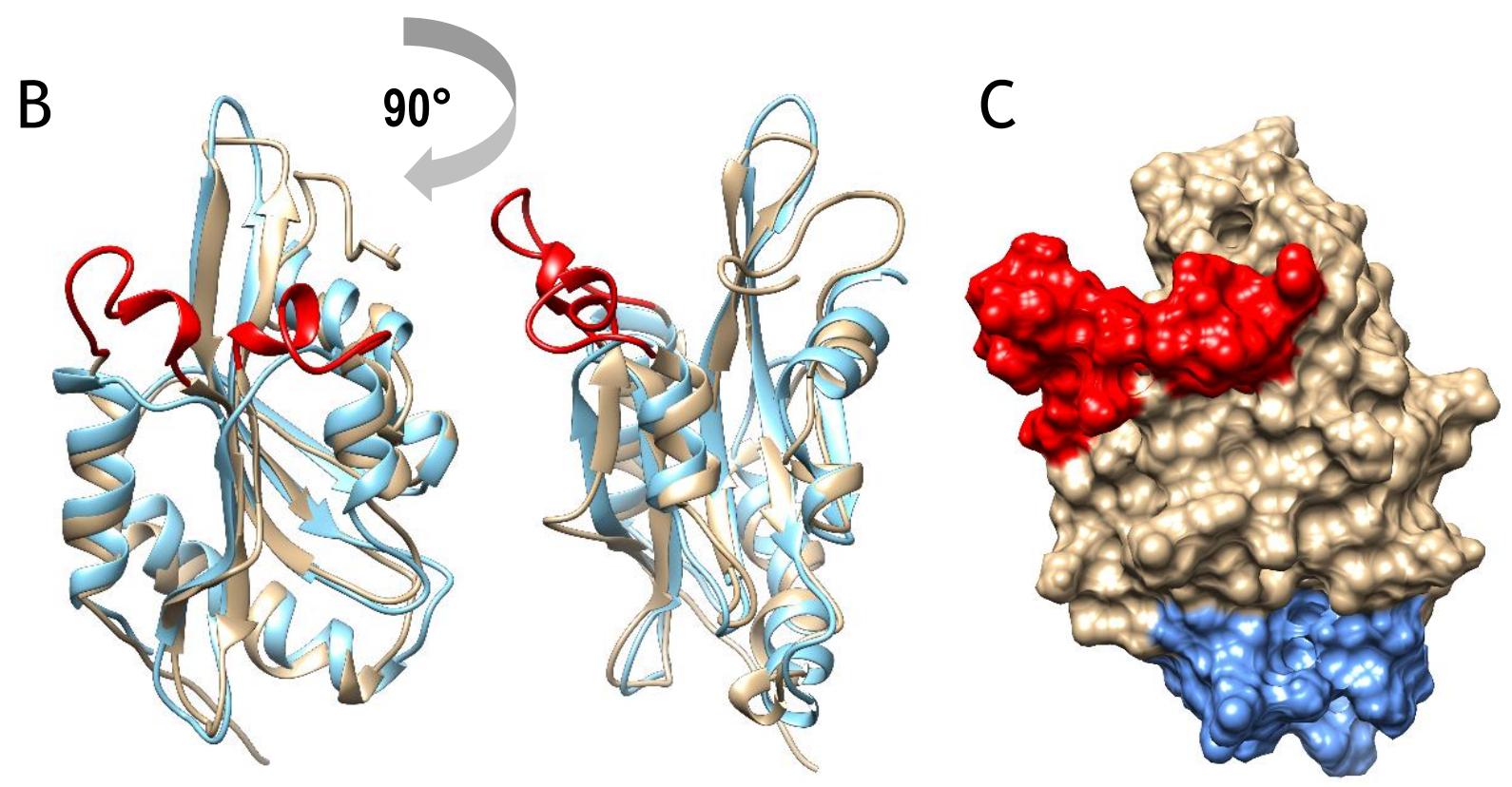




\section{SUPPLEMENTAL MATERIAL}

Supplemental Figure 1. Differences in the sequential compositions of vertebrate and nonvertebrate ADF/cofilins.

Sequence alignment of vertebrate and non-vertebrate ADF/cofilins showing the lack of conservation of the hydrophilic loops (the corresponding sequence elements are highlighted by red in vertebrates). Pfam IDs and source organisms are given. 


\section{Supplemental Figure 1.}

Q9Y281 COF2_Homo sapiens P18760 COF1 Mus musculus P45591 COF2_Mus musculus P23528 COF1 Homo sapiens Q03048 COFI-S. cerevisiae Q966T6 COF2 ${ }^{-}$D. discoideum Q8I467 CADĒ̄ P.falciparum Q6CQ22 COFI_KIuyveromyces lactis P86293 CADF $\overline{2}$ _P.falciparum

A4I4A3 A4I4A $\overline{3}$ Leishmania infantum B9Q2C8 B9Q2C8_Toxoplasma gondii Q39250 ADF1 A. thaliana Q3YPHO Q3YP $\bar{H} 0$ Plasmodium berghei

------MASGVTVNDEVIKVFNDMKVRKSSTQEEIKKRKKAVLFCLSDDKRQI IVEEAK 53 ------MASGVAVSDGVIKVFNDMKVRKSSTPEEVKKRKKAVLFCLSEDKKNI I LEEGK 53 ------MASGVTVNDEVIKVFNDMKVRKSSTQEEIKKRKKAVLFCLSDDKRQI IVEEAK 53 ------MASGVAVSDGVIKVFNDMKVRKSSTPEEVKKRKKAVLFCLSEDKKNI I LEEGK 53 -----MSRSGVAVADESLTAFNDLKLGKK--------YKFILFGLNDAKTEIVVKETS 45 MSAPLSPSPTVVKLSPECQQYYQDVRIKNK---------YQGVVYKINKESNQMIIDKTF 51 ------MISGIRVNDNCVTE FNNMKIRKT--------CGWIIFVIQNCEIIIHSKGAS 44 ------MSRSGVAVADESLNAFNDLKLGKK---------YKFILYALNDSKTEIIVKETS 45 ------MVSGVKVSDECVYEFNKLKIKHI---------HKYIIYRIENYEEVIVDELEQ 44 -----MAISGVTLEENVRGAIDDLRMKKS---------RYVMMCIGADGKKIEVTEVG 44 ------MASGMGVDENCVARFNELKIRKT---------VKWIVFKIENTKIV--VEKDG 42 ----MANAASGMAVHDDCKLRFLELKAKRT--------HRFIVYKIEEKQKQVVVEKVG 47 ------MVSGVNVSDECIYEFNRLKVKHL---------NKYIIYKIENLEKIVVDVLEH 44 $:$ : : : : . : :

OILVGDIGDTVEDPYTSFVKLLPLNDCRYALYDATYETKE--SKKEDLVFIFWAPESAPL 111 EILVGDVGQTVDDPYTTEVKMLPDKDCRYALYDATYETKE--SKKEDLVFIFWAPENAPL 111 QILVGDIGDTVEDPYTSFVKLLPLNDCRYALYDATYETKE--SKKEDLVFIFWAPESAPL 111 EILVGDVGQTVDDPYATFVKMLPDKDCRYALYDATYETKE--SKKEDLVFIFWAPESAPL 111 $-------T D P S Y D A F L E K L P E N D C L Y A I Y D F E Y E I N G N E G K R S K I V F F T W S P D T A P V 95$ --------PNDCNFNELTQCFKENECCIIVFKYVISNSQ-----SKLFFIYWGSETAPQ 97 --------TTLTELVQSIDKNNEIQCAYVVEDAV---------SKIHFFMYARESSNS 85 -------AEQDYDKFLEQLPENDCLYAVYDEEYELGNNEGKRSKIVFFTWSPDTAPV 95 DNSLK----SYKDIIIDIRNNLKTTECRYIIADMPIPTPE-GVLRNRIYFIFWSPDLAKS 99 $-------E R S V N Y T D L K K K F S T E K P C Y V A F D F E Y N D A G--S K R E K L I L I Q W I P D T A R P 93$ -------K--GNADEFRGALPANDCRFGVYDCG---------NKIQFVLWCPDNAPV 81 --------QPIQTYEEFAACLPADECRYAIYDFDFVTAE-NCQKSKIFFIAWCPDIAKV 97 DMELT----SLDNIIMRIKNNLKNTECRYIIADMPIPTPE-GVLRDRIYFIFWSPGLSKP 99

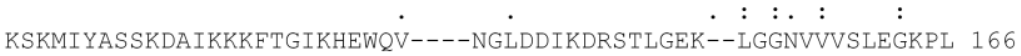
KSKMIYASSKDAIKKKLTGIKHELQA----NCYEEVKDRCTLAEK--LGGSAVISLEGKPL 166 KSKMIYASSKDAIKKKFTGIKHEWQV----NGLDDIKDRSTLGEK--LGGSVVVSLEGKPL 166 KSKMIYASSKDAIKKKLTGIKHELQA----NCYEEVKDRCTLAEK--LGGSAVISLEGKPL 166 RSKMVYASSKDALRRALNGVSTDVQ----GTDFSEVSYDSVLERVSRGAGSH--------- 143 TDKVLYSNAKLTLAITLKGIDIKIAGT----KKSELTEEIFKERAIPKQA----------- 143

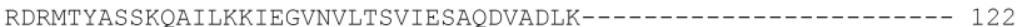
RSKMVYASSKDALRRALNGVSSDIQ----GTDESEVAYESVLEKVSRAAGSH--------- 143 KEKMLYASSKEYLVRKINGIFKSLEITCDLEDEEDELRTI ILNT--------------- 143 REKMMYSASRDALSSVSEGYLPIQANDESGLDAEEIIRKVRLHRSV-------------- 139 KPRMTYASSKDALLKKLDGATAVALE---AHEMGD--LAPLA----------------- 118 RSKMIYASSKDRFKRELDGIQVELQ----ATDPTEMDLDVFRSRAN--------------- 139 KEKMLYAASKESLVRKINGIFKSLEITCDINEFEEELKAIILNT---------------- 143 $:{ }^{*}::: \quad$ : $\quad$ : 